\title{
New estimates of potential impacts of sea level rise and coastal floods in Poland
}

\author{
Dominik Paprotny ${ }^{1} \cdot$ Pawel Terefenko $^{2}$
}

Received: 19 November 2015/ Accepted: 6 October 2016/Published online: 15 October 2016

(C) The Author(s) 2016. This article is published with open access at Springerlink.com

\begin{abstract}
Polish coastal zone is thought to be one of the most exposed to sea level rise in Europe. With mean sea levels expected to increase between 28 and $98 \mathrm{~cm}$ by the end of the century, and storms increasing in severity, accurate estimates of the consequences of those phenomena are needed. Recent advances in quality and availability of spatial data in Poland made possible the reassessment of previous estimates of inundation caused by sea level rise. Up-to-date, detailed information on land use, population and buildings was used here to calculate their exposure to floods at a broad range of scenarios. Inclusion of a highresolution digital elevation model contributed to a further improvement in estimates. The results revealed that even by using a static "bathtub fill" approach, the amount of exposed land, population or assets is significantly smaller than indicated in previous assessments. In the perspective of the twenty-first century, direct damages caused by sea level rise will be small and adaptation costs will not be significant. However, the increase in the frequency of storm surges could elevate the risk to the population and economy, but cost-effective flood protection measures would be able to mitigate the risk. The exposure of different kinds of assets and sectors of the economy varies to a large extent, though the structural breakdown of potential losses is remarkably stable between scenarios.
\end{abstract}

Keywords Sea level rise $\cdot$ Coastal floods $\cdot$ Poland · Flood risk · GIS

Electronic supplementary material The online version of this article (doi:10.1007/s11069-016-2619-z) contains supplementary material, which is available to authorized users.

Dominik Paprotny

d.paprotny@tudelft.nl

1 Department of Hydraulic Engineering, Faculty of Civil Engineering and Geosciences, Delft University of Technology, Stevinweg 1, 2628 CN Delft, The Netherlands

2 Remote Sensing and Marine Cartography Unit, Faculty of Geosciences, University of Szczecin, Mickiewicza 18, 70-383 Szczecin, Poland 


\section{Introduction}

Storms surges are an important factor shaping the Polish coast. Short-term water level variations caused by them significantly alter the coast in the non-tidal Baltic Sea, where extreme water levels depend largely on the volume of water flowing in from the North Sea. Several large coastal floods occurred in late nineteenth and early twentieth century, with a few calmer decades thereafter. More recently, however, storms have been on the rise: the number of surges exceeding the warning level of approximately $70 \mathrm{~cm}$ above mean sea level (MSL) soared from about two per year in the 1950s to six per year in 2000s (Wiśniewski and Wolski 2009). Usually these events are too short to cause damages inland. However, during a storm surge in January 1983 water levels exceeded $1.3 \mathrm{~m}$ above MSL along the most of the coast, affecting many locations, particularly in the eastern part. In the Żuławy region, a total of $50 \mathrm{~km}^{2}$ of land was flooded and almost 1300 people were evacuated (Bednarczyk et al. 2006). Wiśniewski and Wolski (2009) estimated that a 100 -year coastal flood could be as high as $1.95 \mathrm{~m}$ above average in Kołobrzeg, while a 1000 -year flood might reach $2.5 \mathrm{~m}$; the highest value actually recorded was $2.22 \mathrm{~m}$ in 1872.

Long-lasting storm surges, even though relatively insignificant at the coast, can cause a flood dozens of kilometres inland, on the low-lying parts of Odra and Vistula fluvial plains. In those estuaries, water levels could even be higher than at the coast; this happens when large volumes of water flow in from the sea due to the northerly winds (Wiśniewski and Kowalewska-Kalkowska 2007). The highest recorded water level in Szczecin, located almost $70 \mathrm{~km}$ inland, was $1.54 \mathrm{~m}$ above average during a storm surge in 1913 (Richter et al. 2012). The most recent storm surge resulting in a large inflow of seawater into the river network occurred in 2009, causing losses of several million euro in locations all over the coast, mainly in the eastern part (KZGW 2011). Across the whole region, flood defences protect the lowest areas, particularly around river mouths and coastal lakes, while the rest of the coast is protected by nature.

At a longer timescale, the contemporary sea level rise (SLR) triggered by the changing climate is also a threat to coastal areas. It is generally considered (Church et al. 2013; Hunter 2010; Wróblewski 1994) that the increase in mean sea level will directly translate into higher storm surge maxima. It is therefore necessary to assess the number of persons and value of assets which could be at stake. In Poland, comprehensive research on coastal flood risk considering sea level rise was originally spawned by IPCC's first assessment report released in 1990. Rotnicki and Borówka (1991) used 1:25,000 topographic maps to calculate the area threatened by rising waters along with a quantification of assets affected, such as land use, infrastructure, settlements and their population. According to an expanded version of that study (Rotnicki et al. 1995), a 2.5-m SLR would impact $2700 \mathrm{~km}^{2}$ of land, including $93 \mathrm{~km}^{2}$ of settlements, $374 \mathrm{~km}$ of railways, $906 \mathrm{~km}$ of roads and 297,000 people. Based on the results of Rotnicki's and Borówka's (1991) study, Pluijm et al. (1992) calculated the monetary value of land and structures exposed to sea level rise. The results indicated that a 1-m rise of mean sea levels would result in a loss of assets worth $24 \%$ of 1990 gross domestic product (GDP). This study was later updated with newer economic data by Zeidler (1997), whose results were in turn reused by Pruszak and Zawadzka $(2005,2008)$ and cited in several global assessments of sea level rise (e.g. Nicholls and Mimura 1998; Nicholls and Klein 2005). In effect, published assessments of the effects of sea level rise are limited to delimitations of hazard zones made in late 1980s (the earliest version of the study by Rotnicki and Borówka was published in 1989) and 
socio-economic data from the early 1990s. Poland was included in studies on global and European flood risk based on DIVA model—most recently by Hinkel et al. (2014) — though only Hinkel et al. (2010) and Bosello et al. (2012) included a breakdown of impacts by country. All of these studies used only low-resolution data and were characterized by a high degree of generalization. For instance, only a most recent analysis (Mokrech et al. 2015) included flood defences in the calculation of flood hazard in Europe and only using assumptions of protection levels. Still, no information on country-level impacts was provided.

More recently, due to the obligations imposed by the European Union's "flood directive" (EU 2007), the national government ordered preparation of flood risk maps for selected regions of Poland. They were published in 2013 by the National Water Management Authority (KZGW 2015). Their main advantage is the use of up-to-date, detailed and high-resolution data, including lidar-derived digital elevation models (DEMs), aerial photography, land surveys and administrative registers. However, the main focus has been put on river floods, while only parts of the coast were investigated. Moreover, no sea level rise impacts were assessed, while the analysis of storm surges was limited only to one or two scenarios, depending on location. Finally, the results of flood risk calculations are provided only as a graphical representation on maps, and the only aggregate statistics provided are the estimates of exposed inhabitants per settlement. The total value of exposed assets was not disclosed.

In the light of the above, there is clearly a need for a high-resolution assessment of possible social and economic impacts of storm surges and inundation of land caused by sea level rise in Poland. This is particularly important as the existing studies all indicated that very severe consequences for the population and economy might occur in the twenty-first century. In this paper, we aim to provide more precise estimates of exposure of land, population and assets at a broad range of scenarios, using the up-to-date and detailed cartographic materials, which have become available only recently. Most importantly, the digital elevation model used here includes the majority of flood defences in the area, which were missing in other studies. The main aim is to provide a dataset, which could be used to various, frequently changing, projections of climate, population and economic growth. Furthermore, we analyse the data in the context of IPCC projections, as well as discuss the adaptation measures.

\section{Materials and methods}

\subsection{Regional setting}

The Baltic Sea is a non-tidal, semi-enclosed and shallow body of brackish water. Exchange of water through the Danish Straits is the primary regulator of water levels in the basin, causing dangerous surges primarily at its southern and eastern coasts (Ekman 2009; Wolski et al. 2014). Poland has a 500-km-long, diversified coastline. At various locations along the coast, there are sections of cliffs totalling ca. $18 \%$ of entire coastline length (Tomczak 1995). Apart from an alluvial section in the Puck Lagoon (less than $3 \%$ of the total), the remainder is a spit- and barrier-type coast, with dunes ranging in height from less than 2 up to $49 \mathrm{~m}$. Behind the dunes, coastal plains with occasional depressions (down to $-1.8 \mathrm{~m}$ MSL) are usually observed. 
Tide gauge in Świnoujście, at mouth of Odra Estuary in the Baltic Coast, has one of the longest instrumental records in the world (Permanent Service for Mean Sea Level 2015), and during 1811-2006, a trend of $0.4 \mathrm{~mm}$ per year was observed here, accelerating to $1.0 \mathrm{~mm}$ per year during 1947-2006 (Wiśniewski et al. 2011). This rate rises moving eastward: Kołobrzeg (central part of the Polish coast) recorded an increase of $0.5 \mathrm{~mm}$ during 1901-2006 and $1.4 \mathrm{~mm}$ during 1947-2006, while in Gdańsk (eastern coast), $1.6 \mathrm{~mm}$ increase was observed during 1886-2006 and $2.5 \mathrm{~mm}$ during 1947-2006. The difference is largely due to uneven isostatic movement of the crust. Global mean sea level has risen by $21 \mathrm{~cm}$ between 1880 and 2009 (Church and White 2011), or $1.6 \mathrm{~mm}$ per year. Also, satellite altimetry reveals that the rise in water levels is mostly uniform in the southern Baltic Sea. It amounted to $3.2 \mathrm{~mm}$ per year between 1992 and 2016, a pace very similar to the world ocean average, which was $2.9 \mathrm{~mm}$ per year during 1992-2016 (NOAA 2016).

Although as much as $7 \%$ of world population lives within $20 \mathrm{~km}$ from the coast (Kummu et al. 2016), the Polish Baltic Sea coast itself is not densely inhabited: only $2.8 \%$ of Poles reside in municipalities with direct access to the sea. Excluding the large Tricity agglomeration (Gdańsk, Sopot, Gdynia), the population density in this area is a mere 90 persons per $\mathrm{km}^{2}$ which is quite low when compared to the national average of 123 (CSO 2015). However, the coast is by far the most popular vacation destination in Poland. Thirtyfive percentage of all overnight stays in accommodation establishments during July-August 2013 occurred in 55 municipalities considered by Eurostat as coastal regions (CSO 2015). That corresponds to an average of 71 tourists per 100 residents during the summer. The economies of many coastal resorts are completely dependent on this short holiday season (Łonyszyn and Terefenko 2014). Any damages to infrastructure and buildings could therefore dampen the economic prospects of those localities.

The study area, as referred to hereafter, includes all municipalities, not necessarily bordering the Baltic Sea, in which there is some land laying no more than $5 \mathrm{~m}$ above mean sea level. There are 86 such municipalities, including 22 that further divide into a town and a rural area. That sums up to 108 basic administrative units with a combined population of 2.4 million (at 2011 census according to CSO 2015). Figure 1 outlines the study area within the Polish coastal zone.

\subsection{Data sources}

Two main sources of data were used in this study: the topographic objects database containing information on land use as well as buildings, and a digital elevation model (DEM). Both were derived from national cartographic repository (CODGiK 2014, 2016), which include recent output of large-scale mapping projects. Statistical data on demographic and economic indicators have also been collected.

\subsubsection{Digital elevation models}

Quality of flood hazard analyses depends mainly on detailed information on the terrain in question. Here, a digital elevation model created through airborne laser scanning technology (lidar) was used. DEMs obtained using this method are commonly applied to coastal flood hazard analyses because of their accuracy (Webster 2010). In recent years, the national government launched a large measurement campaign specifically to provide data for flood hazard mapping, which was carried out in the coastal areas between 2010 and 2013 (mainly in 2011). The density of scanning was usually 4 points per $\mathrm{m}^{2}$, except for 


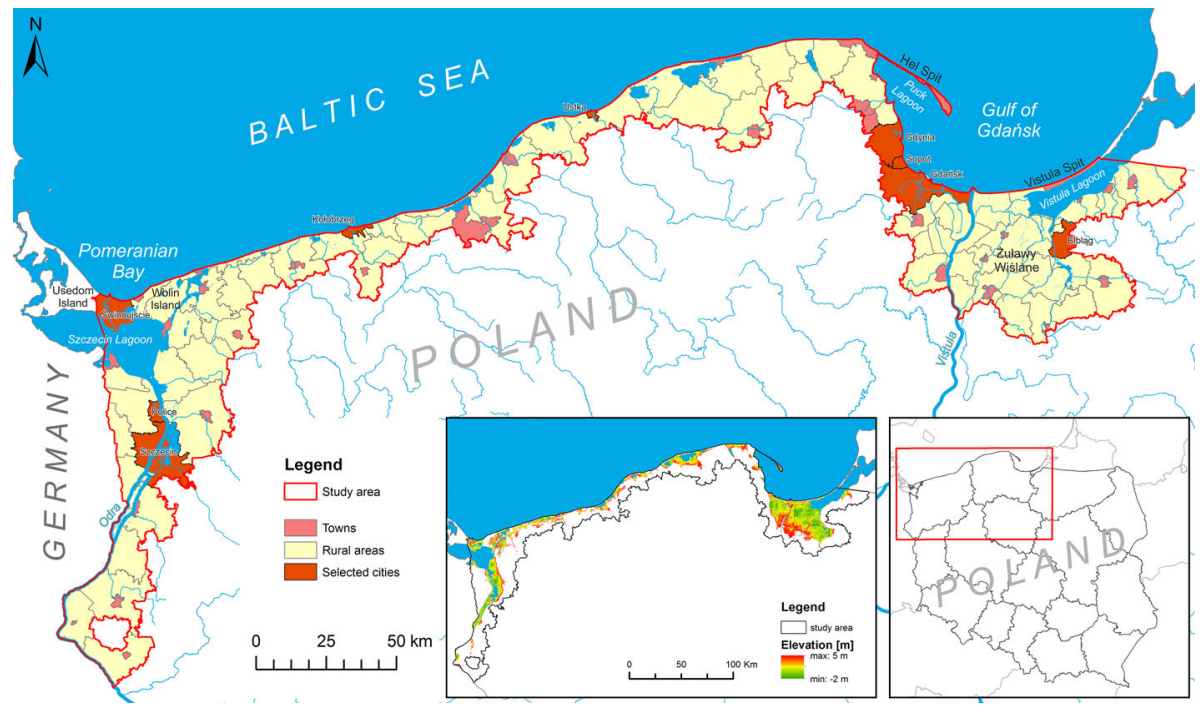

Fig. 1 Study area (all municipalities with some land lying below $+5 \mathrm{~m} \mathrm{MSL}$ ) and the Polish coastal zone. The inner map presents elevation values

urban agglomerations, where the density was 12 points per $\mathrm{m}^{2}$. The final dataset in raster format has a spatial resolution of $1 \mathrm{~m}$, which is fine enough to include flood defences and most of other small topographic features that can have a profound impact on flood hazard analyses. Average vertical error of the dataset is nominally less than $20 \mathrm{~cm}$ in areas with scanning density of $4 \mathrm{pts} / \mathrm{m}^{2}$ and less than $10 \mathrm{~cm}$ in areas scanned with $12 \mathrm{pts} / \mathrm{m}^{2}$ (CODGiK 2014). Yet, the DEM has some other imperfections. A large low-lying area, which in reality is protected by higher terrain or flood defence structures, can be marked as potentially flooded if a minor error in the data creates a "gate" for floodwater. Also, some of the hydraulic structures used to manage river flow and maritime transport, such as locks, sluices and weirs, are mostly not present in the DEM.

A very small area located in the western part of the coastal zone is not covered by the detailed lidar DEM. The gap was filled with a different DEM, which was created on the basis of aerial photographs. It has a spatial resolution of $40 \mathrm{~m}$ and a vertical accuracy of about $1.5 \mathrm{~m}$. These are much worse values than for the lidar DEM, but it had to be used only for less than $0.1 \%$ of the exposed area, so it has a negligible impact on the results.

\subsubsection{Topographic objects database}

The primary source of information on land use and buildings used here is the topographic objects database, the digital successor of analogue topographic maps, created and maintained by Poland's surveyor general (CODGiK 2016). It consists of almost 300 types of objects with a vectorized representation of their geometry and additional qualitative and quantitative descriptors. Accuracy of the database in terms of location and minimum size of objects approaches a 1:10,000 topographic map. This is enough to represent the natural and socio-economic environment down to a single parcel, road and building. The current structure of the database was implemented in 2011 (Law 2011/279/1642), and its content was updated during 2012-2013. The database used here corresponds to the state of 
January-July 2013, depending on location. Quantitative information on the objects, such as their area, is expected not to deviate from real values more than $\pm 20 \%$.

Data on buildings include their area, functional characteristic and, in most cases, the number of storeys. In case the latter is missing, the building was assumed to have only one storey. Roads are represented in the database as a linear object, but for each section, their width is given, so that they could be transformed into a surface. Only paved roads were included in the calculation. Railway and tramlines were transformed into polygons according to the gauge of the tracks. Roads and tracks located on bridges or similar aboveground structures were excluded.

\subsection{Calculation of flood hazard}

\subsubsection{Inundation}

Flood hazard analysis involves calculation of the inundation extent and other hydrological parameters of the flooding, such as water depth. To calculate the flood zone, a "bathtub fill" approach was applied for this study (Bates and De Roo 2000; Poulter and Halpin 2008). It is assumed that the sea at a certain scenario will cover all land lying below the assumed water level, as long as there is a direct connection with the source of flood. For the analysis of inundation caused by sea level rise, that is an accurate description. However, for storm surges it is a straightforward simplification. The method does not take into account the kinematics of the flow or sedimentation processes and considers flooding as an instantaneous process. The temporal change in water levels is also an important factor determining the inundation extent. Unfortunately, the data required to include time in such a calculation were not available to the authors. In effect, the storm surge scenarios constitute a description of the worst-case event (Apel et al. 2009; Breilh et al. 2013). The biggest advantage of the chosen method is a possibility of a direct comparison of achieved results with previous studies performed in the Baltic coast. The possibility of directly implementing the method in the geographical information systems is also useful. On the other hand, dynamic effects such as erosion and sedimentation were not included.

The resolution of the DEM is fine enough to include flood defences; therefore, isolated locations, i.e. having no direct connection with the sea, lying below the water level at a given scenario were considered protected by the surrounding high terrain. These areas were discarded to create the final flood zone using a four-side rule, which means that no water flow was allowed in diagonal directions (Poulter and Halpin 2008). Naturally, dikes and other structures could fail and flood the hinterland, but that aspect was not considered in this article. Also, the situation when water floods the land behind structures through culverts was not analysed. Protection from flood defences such as dikes, banks and other earthworks, as well as sluices and weirs is included in the calculation.

The GIS analysis itself was performed using the ArGIS 10 software. Raster datasets with information on elevation (CODGiK 2014) were combined to generate a complete grid of the study area. The grid was then reclassified into two distinct classes: above and below the analysed sea level. The result was a two-coloured map showing the land and the inundation. The latter class was transformed into a vector polygon, and its connection with the sea was investigated by selecting only those polygons that are intersecting with the water at normal level. The resulting polygons were clipped with a mask representing Polish borders in order to delimit the final area at country level. Further analysis included intersections between inundated area for each water level and different layers representing buildings, land types, etc. extracted from the topographic objects database (CODGiK 2016) 
as well as grouping the results into different systematic classes according to administrative divisions.

\subsubsection{SLR and storm surge scenarios}

Sea level rise and storm surges were analysed in intervals of $5 \mathrm{~cm}$, providing scenarios of $5,10,15$, etc., $\mathrm{cm}$ up to $5 \mathrm{~m}$ above mean sea level. In this way, the exposure of population and assets at different elevations could be assessed in detail. The 5-m value was chosen as the rounded value of the maximum possible SLR indicated in the literature (1.4-2 $\mathrm{m}$ in Rahmstorf 2007; Pfeffer et al. 2008) together with a 1000-year coastal flood (about $+2.5 \mathrm{~m}$ MSL according to Wolski et al. 2014). Mean sea level along the Polish coast varies slightly, with 1947-2006 average in Gdańsk being $7 \mathrm{~cm}$ higher than in Świnoujście (Wiśniewski and Wolski 2009). As a minor simplification, the $500 \mathrm{~cm}$ "baseline" level of all Polish tide gauges was used here as MSL, which corresponds to about $+0.10 \mathrm{~m}$ in the European Vertical Reference System EVRS-2007 (Urbański 2012).

The results are also juxtaposed here with future sea level rise scenarios included in the latest IPCC report (Church et al. 2013). Three scenarios are considered: the medium projection for RCP4.5 and the lowest and highest of the projections (lower bound of RCP2.6 and upper bound of RCP8.5). In those scenarios, water levels rise gradually to 28 , 53 and $98 \mathrm{~cm}$ SLR by 2100 relative to 1986-2005 levels. However, Polish coast is subject to the glacial isostatic adjustment, which causes a yearly uplift by about $0.4-0.5 \mathrm{~mm}$ (Peltier et al. 2015). Increase in water levels is also uneven regardless of the movement of the coast; satellite-measured SLR trend during 1992-2015 was between 4.2 and $4.3 \mathrm{~mm}$ per year in the Baltic along the Polish coast; only in the far western part, it was slightly higher, up to $4.5 \mathrm{~mm}$ per year (NOAA 2016). These two effects translate to a difference of only a few centimetres in a perspective of a century. Bigger spatial differences in SLR can be caused by ground subsidence, which is a very local factor; no large-scale data are available on this matter. Therefore, IPCC scenarios were applied in the analysis without modifications.

For the analysis of coastal floods, the return periods of storm surges were calculated. They vary along the coast and lagoons; therefore, the return periods were calculated from annual maximum water levels recorded at eight gauges during 1948-2007. To each station (5 coastal, 1 in the Szczecin Lagoon and two on Odra river), the nearest basic administrative units were assigned. Water level data from Wiśniewski and Wolski (2009) were used and fitted to Gumbel probability distribution; details on the methodology can be found in Paprotny (2014).

\subsection{Calculation of flood risk}

Flood risk is a combination of three elements, as follows:

- Hazard, i.e. factor that can cause adverse effects, in our case sea level rise and coastal floods (see previous section);

- Exposure, i.e. the inventory of elements that could potentially be affected by the hazard;

- Vulnerability, i.e. the propensity of exposed elements to be adversely affected by the hazard event (Kron 2005; Cardona et al. 2012). 
In this section, we present the methodology to calculate exposure and vulnerability in order to obtain an estimate of risk caused by sea level rise and coastal floods in context of SLR.

\subsubsection{Calculation of exposure}

Following Hallegatte's (2012) framework on investigating impact of SLR on economic growth, we analyse exposure to the following elements:

- Permanent losses of natural capital: market value of land, including an estimate of the area of protected habitats,

- Permanent loss of physical capital: gross replacement cost of immovable and movable fixed assets,

- Permanent loss of social capital: number of inhabitants.

Value of aforementioned assets was calculated here using 2011 data, the latest year for which complete statistics required here were available. The primary source was the online databases of the Central Statistical Office of Poland (CSO 2015). Values of land under different types of use are an estimate of their 2011 market price. Average sale price calculations made by CSO were used for arable land, meadows and pastures. Value of forests was taken from estimates of the State Forests, the manager of the vast majority of Polish woods (Ministry of Treasury 2012). Their calculations include both the value of land parcels and the trees covering them. Value of areas covered by buildings, transport infrastructure or non-built-up areas ready for construction was estimated using the relation between the sale price of those types of land use and the sale price of arable land in Germany in 2011 (Statistisches Bundesamt 2015). For other types of land use, numbers were assigned based on governmental regulations on estimation of real estate value (Law 2004/207/2109). As a result, woodlands or bushes are assumed to be worth equal to poorquality arable land. Orchards were assigned the same value as arable land, while wastelands and other unutilized land were considered as equal to poor-quality meadows. Loss of inland surface water was not taken into consideration. Summary of land values is presented in Table 1. Agricultural build-up areas do not form a separate category in the topographic database; it was assumed that build-up areas adjacent to arable land and permanent crops fall into this category.

Table 1 Estimated commercial value of land in 2011 per hectare, in Zloty (the polish national currency, PLN)

4.12 PLN $=€ 1$

\begin{tabular}{lc}
\hline Land use & Value (PLN per ha) \\
\hline Built-up: services & $4,294,000$ \\
Built-up: housing (dense urban) & $2,802,000$ \\
Built-up: housing (scattered urban) & $1,896,000$ \\
Transport areas, non-built-up areas & 559,000 \\
Built-up: agricultural & 453,000 \\
Built-up: industrial & 444,000 \\
Forests & 37,976 \\
Arable land, orchards & 20,004 \\
Woodlands and bushes & 16,401 \\
Meadows and pastures & 14,259 \\
Wastelands and other lands & 12,337 \\
\hline
\end{tabular}


Information on buildings was compiled from several sources in order to calculate their value relative to their area (Table 2). Value of housing is the average construction cost of new houses as calculated by CSO. Stock of movable assets is difficult to estimate, and no national statistics in this matter are available. However, the ratio between household durable goods' value and GDP is reported to differ only slightly between countries and throughout modern history (Piketty and Zucman 2014). It was therefore assumed that the total value in this category in Poland constitutes $35 \%$ of GDP, which is the average ratio in four countries (Canada, Germany, UK and USA) for which data are provided by Piketty and Zucman (2014). GDP and housing area statistics from CSO were used in order to obtain the amount of movable assets per $\mathrm{m}^{2}$ in 2011.

Commercial buildings were divided into three branches (industry, services and agriculture), and for each type, its value was calculated using the following formula:

$$
V=\frac{F \times L_{s}}{L \times A_{s}}
$$

where $V$ is the value of a building per area in PLN, $F$ is the value of fixed assets in Poland, $L_{s}$ is the corresponding land use area in the study area, $L$ is the corresponding land use area in Poland, and $A_{s}$ is the total building area in the study area. Fixed assets estimates were obtained from Eurostat (2015). Land use data for Poland is from CSO (2015), while for the study area, the corresponding types of land use from the topographic database were used. Finally, building area was extracted from the topographic database, taking into account the multiple storeys several buildings contain.

\subsubsection{Calculation of vulnerability}

Assumptions on vulnerability of land and assets are presented in Table 3. In case of rising average water levels, land and immovable fixed assets (i.e. buildings and structures) are covered permanently by water and therefore lost completely. Movable fixed assets, which include machine tools, household goods, vehicles or livestock, can be evacuated from the endangered area given the gradual nature of SLR. Therefore, no losses in this category are

Table 2 Value of fixed assets per area in 2011 and damage functions

\begin{tabular}{|c|c|c|c|}
\hline \multirow[t]{2}{*}{ Type of building or structure } & \multicolumn{2}{|c|}{ Value of fixed assets } & \multirow{2}{*}{$\begin{array}{l}\text { Damage function } \\
Y \text {-damage }(\%), \\
D \text {-water depth (m) }\end{array}$} \\
\hline & $\begin{array}{l}\text { Immovable } \\
\left(\text { PLN per } \mathrm{m}^{2}\right)\end{array}$ & $\begin{array}{l}\text { Movable } \\
\left(\text { PLN per } \mathrm{m}^{2}\right)\end{array}$ & \\
\hline Housing & 3858 & 604 & $\begin{array}{l}Y_{1}=D+18.77 \times \sqrt{D} \\
Y_{2}=4.83 \times D+20.69 \times \sqrt{D}\end{array}$ \\
\hline Industry & 2057 & 1712 & $Y=27 \times \sqrt{D}$ \\
\hline Services & 2678 & 923 & $\begin{array}{l}\text { Market services: } Y=27 \times \sqrt{D} \\
\text { Non-market services: } Y=30 \times \sqrt{D}\end{array}$ \\
\hline Agriculture & 393 & 166 & $Y=27 \times \sqrt{D}$ \\
\hline Transport infrastructure & 436 & - & $Y=\frac{100}{3}$ \\
\hline
\end{tabular}

For housing, $Y_{1}$ is damage to immovable assets and $Y_{2}$ is damage to movable assets 
Table 3 Vulnerability assumptions for sea level rise and storm floods

\begin{tabular}{lll}
\hline Asset & Losses caused by... & \\
\cline { 2 - 3 } & Sea level rise & Coastal flood \\
\hline Land & $100 \%$ & Nil \\
Immovable fixed assets & $100 \%$ & Relative to water depth and type of asset \\
Movable fixed assets & Nil & Relative to water depth and type of asset \\
\hline
\end{tabular}

assumed. In case of coastal floods, no losses are assumed for land, as water covers it only temporarily. Some productivity of land may be lost and consequently its market value could decrease; however, this aspect was not analysed here. Damage to crops is not analysed too, as they are not considered fixed assets, similarly to stocks of produced goods. Losses of fixed assets are calculated using damage functions, which relate losses to water depths (Apel et al. 2009).

Damage functions, which relate water depth to the relative loss of assets, were applied from Emschergenossenschaft/Hydrotec (2004), who created them using HOWAS database of flood losses (Merz et al. 2004). They were selected for this study, because there are no corresponding functions created from Polish empirical data. Additionally, they are similar to damage curves created as a combination of various European methodologies by Huizinga (2007) and suggested for use in countries without national damage functions. The only exception is the damage function for transportation, which is a constant value rather than a damage function. As can be noticed in Table 2, the equations differ for immovable and movable housing assets, while for commercial activity, they are combined. Finally, the value of transport infrastructure was taken from official risk calculations, according to the Polish government's methodology (Law 2013/104). Total value of losses for a building can be described as:

$$
R=A \times V \times Y(D)
$$

where $R$ is the total loss for a building in PLN, A is the building area (including all storeys), $V$ is the total value of the building per area, and $Y(D)$ is the appropriate damage function for water depth $D$ (averaged within the building's contour).

Additionally, the number of people affected by sea level rise and coastal floods was estimated. Population data from the 2011 census (CSO 2015) provide information down to settlement level. By combining these data with housing area from the topographic objects database, it was possible to further disaggregate the data and obtain the average number of persons per housing area in settlements and towns. All persons living in a residential building even partially covered by water were assumed as being affected by the event. Similarly, the amount of tourism traffic potentially lost was estimated by disaggregating the number of tourists and nights spent in establishments (at basic administrative unitlevel) using the size of appropriate categories of buildings. For the purpose of this study, "tourists" refer only to persons staying overnight in collective accommodation, excluding persons in camping sites. 


\subsection{Adaptation measures}

Currently existing flood defences will be put under pressure from rising sea levels. In this section, we outline the methodology to estimate costs of adaptation to the that phenomena. We look at the most popular means of protection, namely dikes. We estimate the length of flood defences using GIS as follows. Firstly, continuous flood zones that contain any buildings are selected. Then, those zones are intersected with a layer representing water at normal conditions (including channels and streams). The length of the intersection lines between the layers was considered as the dike length required for full protection. Because only flood zones with buildings are considered here, some land and pieces of infrastructure will remain unprotected. However, these flood zones are very numerous, yet very small, and would therefore seriously overestimate of the required investments in flood defences.

Dikes have a high marginal cost, which varies enormously depending on location (Jonkman et al. 2013). Average investment in $1 \mathrm{~km}$ of dikes was 1.39 million PLN $(€ 337,000)$ in 2011, according to official statistics (CSO 2015). This value was used as the "fixed" investment value per km, adding $0.7 \%$ for each centimetre of dike crest level, a value used for cost optimization of flood defences in the Netherlands (Eijgenraam 2006). Using annual sea level rise projections, yearly cost of raising the flood defences could be calculated. It is assumed that an upgrade or new construction will be built overnight with a 50-cm safety margin and will be serve without further upgrades until the year 2100 .

A different approach was used for analysing the adaptation to increased storm surge heights. Protection standards of dikes are often chosen arbitrarily. However, it is possible to calculate a flood defence standard in a given location that would be optimal from an economic point of view. In this approach (Van Dantzig 1956; Eijgenraam 2006), investments in flood defences are added to flood damages during the same given period of time. The sum of the two elements reaches a minimum at a certain dike crest elevation; this level constitutes the optimal flood protection. It can be expected that the optimum will shift due to sea level rise. Investments were calculated for each water level as described in the previous paragraph. Risk to assets for each protection standard and SLR scenario was obtained using the following procedure. Firstly, a Monte Carlo simulation was used to estimate the annual losses due to coastal floods $D_{i}$ :

$$
D_{i}=\frac{1}{85} \sum_{t=2016}^{2100} F_{w(t, i)} \times \frac{P_{t}}{P_{2011}}+T_{w(t, i)}
$$

where $t$ denotes the year (2016-2100), $i$ is the iteration in the Monte Carlo simulation, $F_{w(t, i)}$ is the value of buildings, and $T_{w(t, i)}$ is the value of transportation infrastructure affected at water level $w(t, i)$. The latter is a sum of the random storm surge (sampled from the Gumbel distribution) and cumulative sea level rise up to year $t$ at a given scenario. Additionally, the population size $P$ in year $t$ relative to year 2011 was used to approximate the change in value of buildings. The procedure was repeated for each administrative unit 10,000 times and averaged. For each assumed protection level, the values of $F_{w(t, i)}$ and $T_{w(t, i)}$ were set to zero if water level $w(t, i)$ was below the dike height. 2011 prices and GDP were kept constant, therefore assuming that the construction cost of dikes and wealth relative to income will not change in the future, as it is very uncertain how those elements will develop.

Additionally, the number of affected inhabitants per year was obtained similarly to (3): 


$$
E_{i}=\frac{1}{85} \sum_{t=2016}^{2100} P_{w(t, i)} \times \frac{P_{t}}{P_{2011}}
$$

where $P_{w(t)}$ is the number of affected inhabitants under water level $w(t, i)$ in our baseline calculations for 2011. Future population numbers were derived using official projections from CSO (2015) up to year 2050, with an extrapolation of the trend to up to 2100. Those projections are at county level, with rural/urban breakdowns, and thus have far lower resolution than the settlement data used in the baseline calculations. However, no other local-scale demographic forecasts are available; it is therefore assumed that the population in the flood hazard zones will change at the same rate as the population outside them.

\section{Results}

In this section, the consequences of coastal floods and sea level rise are presented. It should be noted that whenever statistics of inundated area are mentioned in the next sections, they do not include land covered by water under normal conditions. Also, all monetary values are in the Polish national currency, Zloty (denoted PLN), in 2011 prices. The exchange rate in 2011 was $4.12 \mathrm{PLN}=€ 1$. Firstly, we present the common socio-economic characteristics of the flood zones for both sea level rise and coastal floods (Sect. 3.1). The estimate of economic losses, which differentiates between the two phenomena, is presented in Sects. 3.2 and 3.3. This is followed by an analysis of the temporal dimension of losses (Sect. 3.4) and adaptation measures (Sect. 3.5). Finally, detailed results, as well as data underlying the figures, can be found in the Supplement.

\subsection{General results}

Water inundates the study area at a different pace depending on the analysed scenario. The flooded area encompasses $342 \mathrm{~km}^{2}$ at $+0.5 \mathrm{~m} \mathrm{MSL}, 1662 \mathrm{~km}^{2}$ at $1.5 \mathrm{~m}$ up to a maximum of $3323 \mathrm{~km}^{2}$ at $5 \mathrm{~m}$ (Fig. 2a). The area at risk grows most dynamically between +0.3 and $+1.6 \mathrm{~m}$ MSL with an average of almost $13 \mathrm{~km}^{2}$ for every $\mathrm{cm}$ of water level rise. The highest growth of $371 \mathrm{~km}^{2}$ is recorded between +1.2 and $+1.3 \mathrm{~m} \mathrm{MSL}$ scenarios (Fig. 2b). Besides that, two other peaks at intervals of 0.8-0.9 and 0.9-1.0 m are observed,

(a)

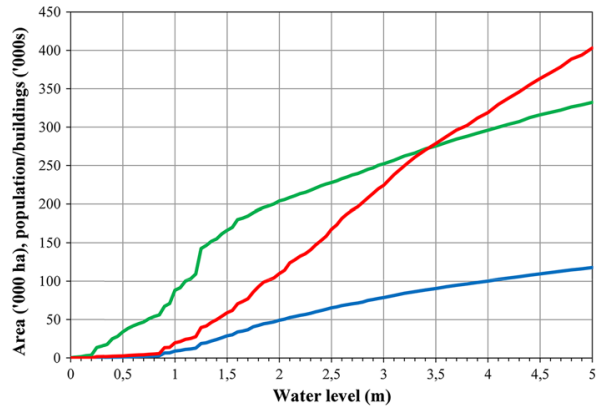

(b)

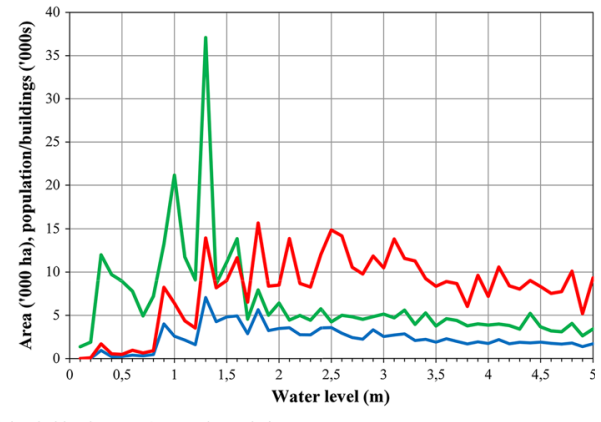

Exposed buildings —Flooded land - Exposed population

Fig. 2 Left Cumulative numbers of exposed land, inhabitants and buildings by water level. Right increments of exposed land, inhabitants and buildings by $10-\mathrm{cm}$ intervals ending with the water level given 
covering 132 and $212 \mathrm{~km}^{2}$, respectively. In the $+1.5-\mathrm{m}$ MSL scenario, the flooded area already reaches half the size of the $+5-\mathrm{m}$ hazard zone, which indicates a significant slowdown in the growth dynamic of the flood zone at higher water levels. Up until the very last scenario, it increases by $3-5 \mathrm{~km}^{2}$ per $\mathrm{cm}$ on average.

The number of affected buildings and inhabitants does not follow the aforementioned tendencies. Urban areas as well as other dense inhabited areas are either protected or generally not located at high-flood-risk zones. This results in an insignificant number of endangered buildings and people up to $+1 \mathrm{~m}$ MSL. Crossing this barrier, in the range from +1.0 to $+2.5 \mathrm{~m} \mathrm{MSL}$, the number of both inhabitants and buildings in the hazard zones soars (Fig. 2b). For buildings, the rate of increase in hazard peaks in the 1.2-1.3 m interval and significantly slows thereafter. Increase in the number of persons affected reaches maximum in the 1.7- to $1.8-\mathrm{m}$ interval and eases only above $+3 \mathrm{~m}$ MSL.

As can be seen in Figs. 3 and 4, flood hazard in the Polish coastal zone concentrates in the Vistula and Odra rivers' mouths. These estuarine regions encompass approximately $75 \%$ of the total flooded area at all scenarios. In the area spread between those two regions along $300 \mathrm{~km}$ of coastline, the flood zones cluster around numerous coastal lakes. Other locations are generally well protected by dunes and cliffs. It should be noted that some

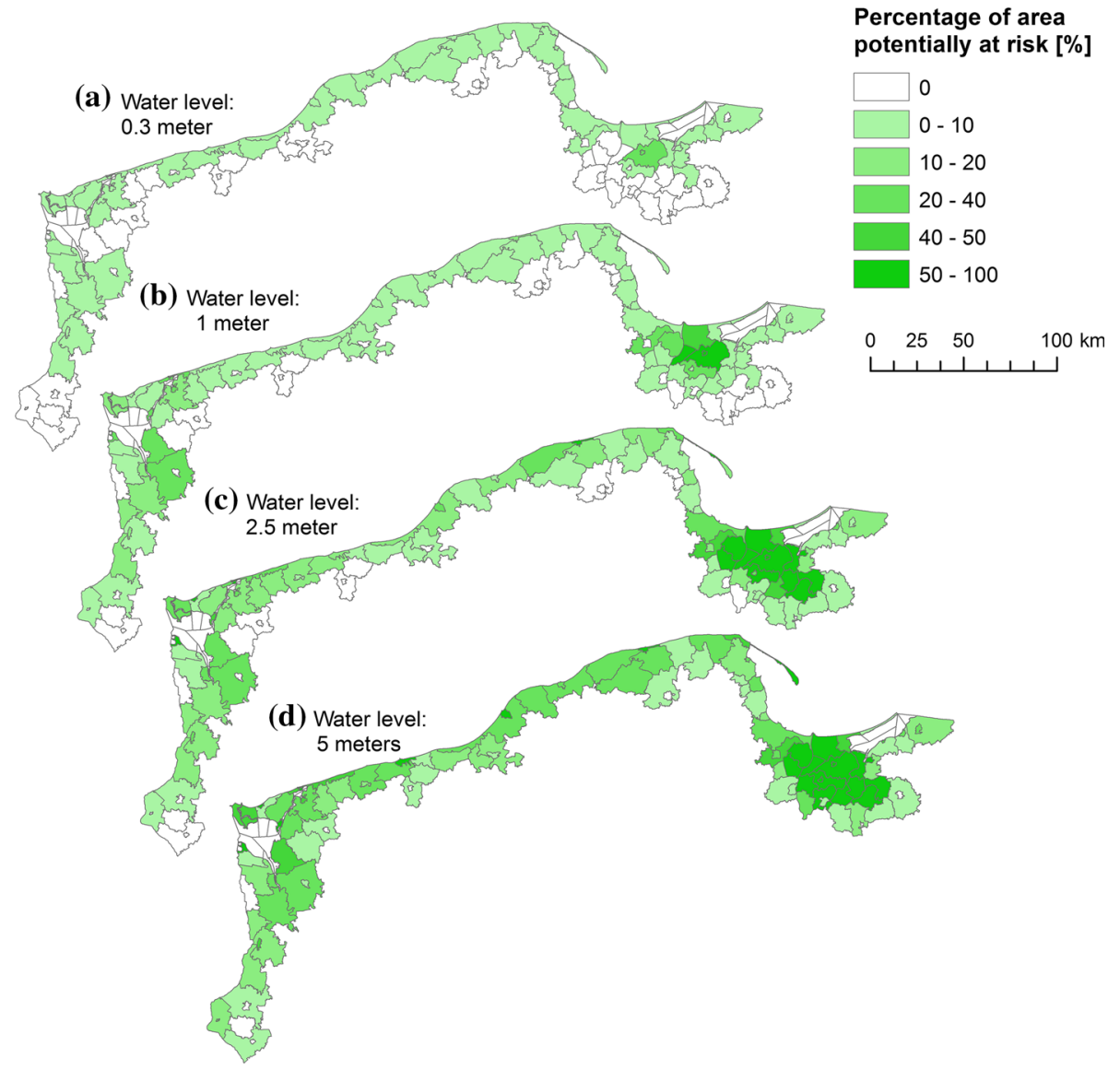

Fig. 3 Percentage of exposed area by water level and town/municipality 


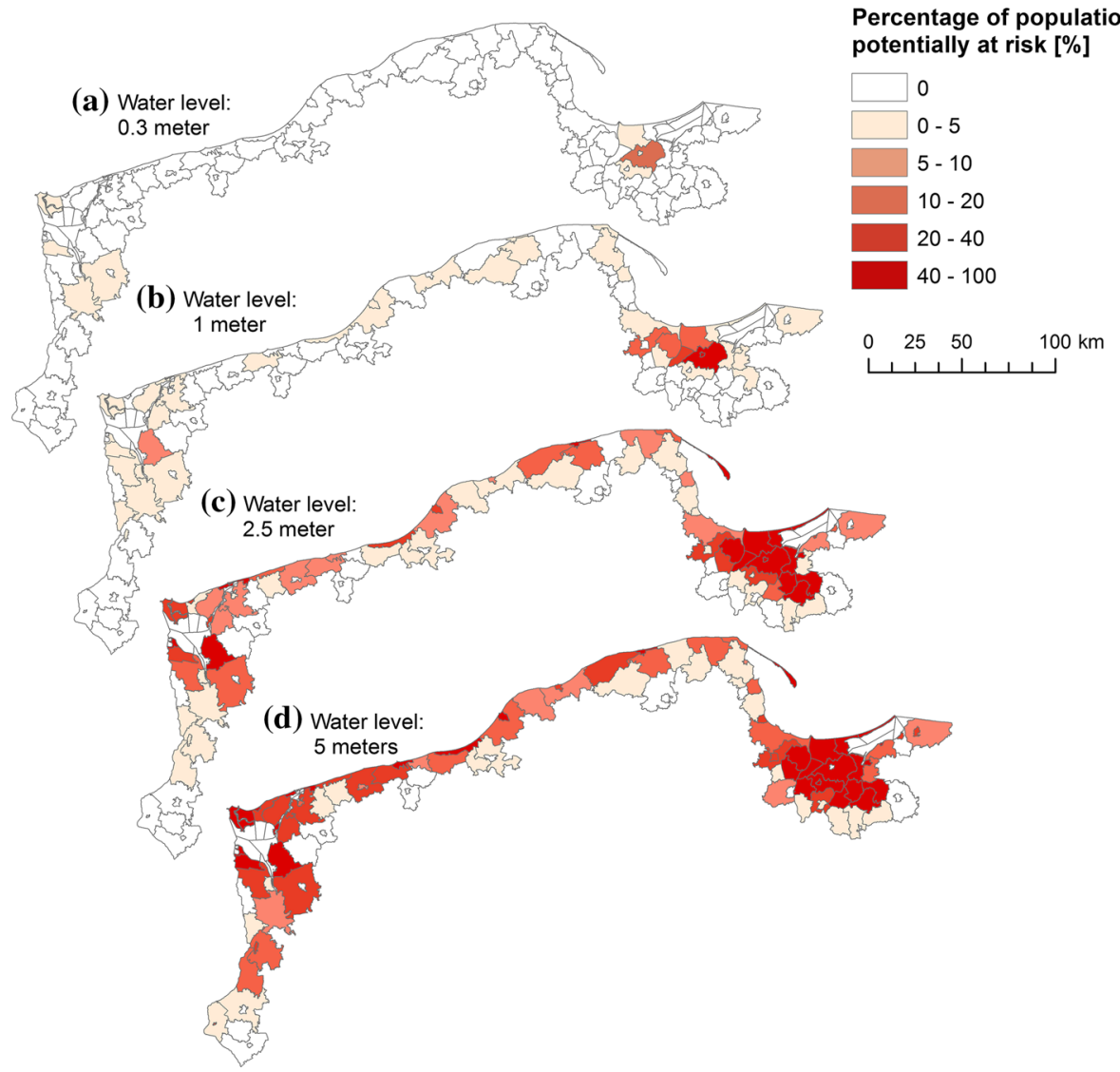

Fig. 4 Percentage of exposed inhabitants by water level and town/municipality

areas can also become surrounded by water without being directly flooded, e.g. the Hel Spit could be severed from mainland at a water level of $+2.4 \mathrm{~m} \mathrm{MSL}$, for instance.

\subsubsection{Population}

Inhabitants residing in rural municipalities or rural parts of rural-urban municipalities are disproportionately exposed to rising water levels. Those units contain $87 \%$ of land area in the region, but only $18 \%$ of its population. Yet, $51 \%$ of inhabitants within $+1 \mathrm{~m} \mathrm{MSL}$ hazard zone live in rural areas. More persons are at risk in urban municipalities than in the rural type only above $+1.7 \mathrm{~m}$ MSL. At $+5 \mathrm{~m} \mathrm{MSL}$, the proportional of rural inhabitants at risk is still higher (26\%) than the regional average. The population in main urban centres comes at risk in larger numbers only above $+2 \mathrm{~m}$ MSL. Gdańsk, located in the Vistula estuary, comprises more than a fifth of inhabitants at risk in scenarios above $+2.5 \mathrm{~m}$ MSL. Two other urban municipalities in the Tricity are to a vast extent less exposed, with almost no inhabitants in the flood zone below that value. Świnoujście comes second, with exposure soaring above $+1.5 \mathrm{~m}$ MSL, putting the city's contribution to affected inhabitants at $10 \%$ of regional total. 


\subsubsection{Land}

The structure of land in the hazard zones is similar to the general composition of land use both in the region and country. Figure 5 presents the land use divided by five major groups. Barren land, the smallest group representing mainly beaches and dunes, covers more than $5 \%$ of the total flooded area only up to $+0.2 \mathrm{~m}$ MSL. This proportion decreases to $0.7 \%$ by $+5 \mathrm{~m}$ MSL. Grasslands, which are mostly swampy meadows and pastures, constitute more than $85 \%$ of the total area at water levels below $+0.2 \mathrm{~m} \mathrm{MSL}$. It remains the biggest land use group at risk until $+1.25 \mathrm{~m}$ MSL, when croplands come forward. The latter constitute around $43 \%$ of all hazards zones above $+1.25 \mathrm{~m}$ MSL. Natural vegetation represented by woodlands and bushes contribute to about 11-16\% of land at risk, except for areas below the $+0.4 \mathrm{~m}$ MSL. That is less than half of their share in the region (32\%).

Finally, artificial surface category is very diversified, as it comprises areas covered by buildings, infrastructure, landfills and similar human-made structures. Its share slowly increases from around 1 to $6 \%$ by $+5 \mathrm{~m}$ MSL. In general, industrial areas are more exposed than services, especially industrial installations and utilities. Agricultural build-up areas are slightly more at risk than single-family residential zones located further away from croplands. Multi-family residential areas are among the least exposed, with only $1.2 \%$ potentially at risk at $+1.5 \mathrm{~m}$ MSL (single-family-5.8 \%).

It can be added that national parks, landscape parks, natural reserves and Natura 2000 areas also cover a substantial part of the region and are disproportionately exposed: $45 \%$ of their land area is below $+5 \mathrm{~m}$ MSL. It is caused by the specifics of protected land, which consists predominantly of low-lying wetlands, grasslands and forests. In total, $52 \%$ of land in the $+1 \mathrm{~m} \mathrm{MSL}$ zone is under some form of protection, including $77 \%$ of grasslands and $90 \%$ of forests.

\subsubsection{Buildings and infrastructure}

The topographic objects database used for this analysis distinguishes 22 categories of buildings. Figure 6 compares the exposure of selected groups of buildings. Below $+0.7 \mathrm{~m}$ MSL, farmhouses are the main type of buildings in the hazard zone, followed by singlefamily houses. The latter are the biggest group at risk by floor area for virtually every other scenario. Multi-family houses grow in number quickly above $+1.2 \mathrm{~m} \mathrm{MSL}$, but it is not until $+2.5 \mathrm{~m}$ that their floor area exceeds that of farmhouses. This illustrates how areas

(a)

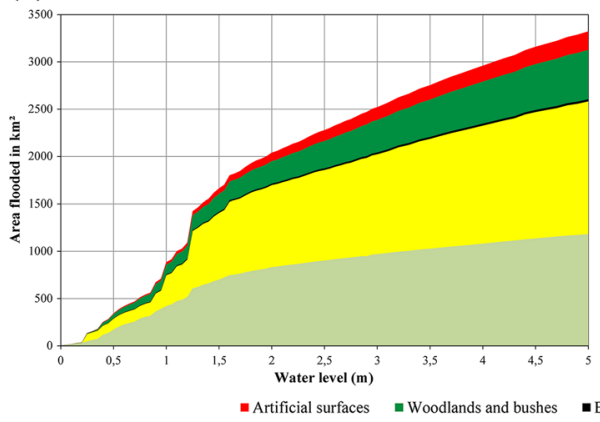

(b)

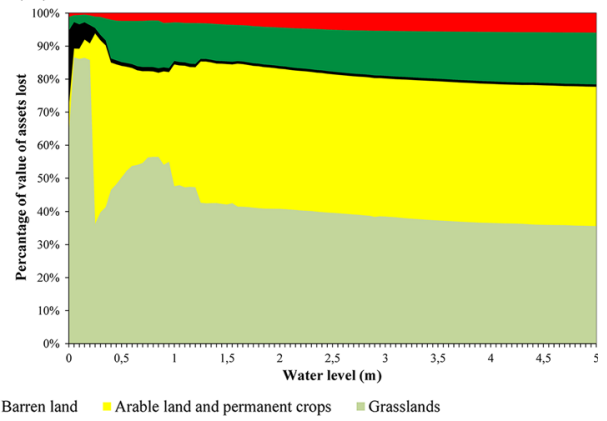

Fig. 5 Exposed area by major groups of land use classes: total area (left) and percentage breakdown (right) 


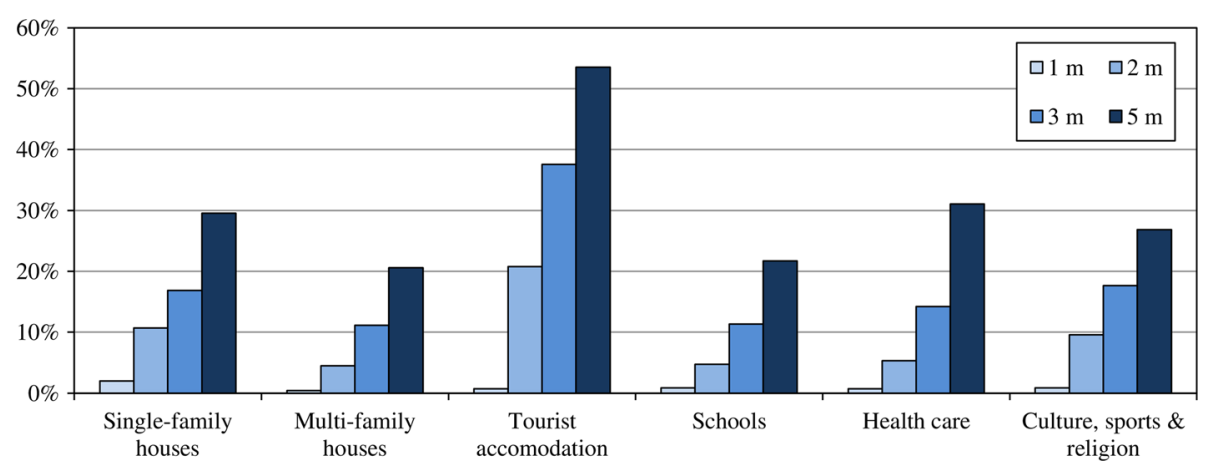

Fig. 6 Exposed buildings as a percentage of all buildings in the category in the study area

outside urban centres, where single-family houses and farmhouses dominate, are vastly more at risk than densely populated urban areas. The proportion of inhabitants living in exposed single-family residences is almost $90 \%$ at $+1 \mathrm{~m}$ MSL and decreases at more extreme scenarios, before converging with houses containing two and more flats at $+4.1 \mathrm{~m}$ MSL. Healthcare buildings are at the beginning among the least endangered group, with barely $2 \%$ located within the $+2 \mathrm{~m}$ MSL hazard zone. This percentage, however, increases vastly thereafter, and buildings used for health services end up as one of the most exposed groups. Other assets disproportionately at risk include warehouses and other storage facilities as well as industrial buildings. On the other end of the scale, schools and trade/services buildings are among the least exposed in both number and floor area.

Tourism is unlikely to be much affected directly. Virtually no tourist traffic (measured both by the number of nights spend or number of visitors) is endangered below $+0.9 \mathrm{~m}$ MSL, near the upper range of SLR projections up to 2100. Tourist accommodation other than hotels is safe at low water levels, but ultimately becomes the most exposed in all scenarios above $+1.45 \mathrm{~m}$ MSL. In case of hotels, the percentage is lower, $48 \%$ compared to $68 \%$ for other accommodation establishments, though it still comes at second place in the 5-m hazard zone. In total, $62 \%$ of tourist nights in the region during 2011 were spent in buildings lying below $+5 \mathrm{~m}$ MSL.

Many buildings in the hazard zones have substantial intangible value. Buildings used for religious practices (mainly catholic churches) are among the least endangered of all 22 categories of buildings analysed. Almost 4400 buildings in the region (1\% of the total) are included in the national heritage sites' list. Below $+2.4 \mathrm{~m} \mathrm{MSL}$, the fraction under threat is narrowly smaller than buildings in overall, but for higher levels, the opposite is true. Museums and libraries are slightly less likely to be in the hazard zone below $+1.7 \mathrm{~m}$ MSL. However, at $+5 \mathrm{~m} \mathrm{MSL}, 47 \%$ of them are at risk; only tourist accommodation buildings have a larger fraction in danger.

Transport infrastructure is generally more exposed than buildings. Paved roads are the most exposed type up to $+2.3 \mathrm{~m}$ MSL; above that value tracks come first, while airstrips are of least concern in all scenarios. For roads, the magnitude of exposure decreases with the increase in its importance. Motorways can only be flooded by water levels rising above $+2.6 \mathrm{~m}$ MSL. Meanwhile, $5 \%$ of expressways could be affected in the $+2.5 \mathrm{~m}$ MSL hazard zone, followed by national and regional roads (both $12 \%$ ), county roads (15\%), municipal roads (16\%), local and private roads (19\%) and company-owned roads (39\%). 
Finally, $18 \%$ of railways are exposed at $+2.5 \mathrm{~m} \mathrm{MSL}$, albeit the figure is somewhat exaggerated due to the numerous sidings located in ports.

\subsection{Economic impact of sea level rise}

Sea level rise causes total loss of land and immovable assets in the affected area. At the lower end of IPCC's SLR projections (+0.3 m MSL), potential losses are estimated to amount to 1.1 bln PLN (0.07\% of 2011 GDP), while on the higher end ( $+1 \mathrm{~m} \mathrm{MSL})$, they soar to 9.6 bln PLN (0.63 \%), as indicated in Fig. 7a. Total value of assets in the $+5 \mathrm{~m}$ MSL zone is 160 bln PLN (10.5\% of 2011 GDP). Notwithstanding, the structure of assets at risk does not change significantly with rising water levels. Figure $7 \mathrm{c}$ presents the breakdown by economic activity for SLR. Assets used for agricultural and forestal production dominate at water levels below $+0.9 \mathrm{~m}$ MSL, as low-lying grasslands, arable land and forests near estuaries and coastal lakes would be flooded first. At higher elevations, housing dominates as the main exposed asset, with the proportion reaching $40 \%$ at $+0.9 \mathrm{~m}$ MSL and gradually rising to a maximum of $53 \%$. Industrial assets fluctuate around $10 \%$, while the percentage associated with the services sector soars to slightly above $20 \%$ at $+1.8 \mathrm{~m} \mathrm{MSL}$ and maintains that level for the remaining scenarios. In agriculture, land is the main source of losses. For other economic activities, losses are predominantly to buildings, with those used for storage worth most up to $+1.3 \mathrm{~m} \mathrm{MSL}$; for

(a)

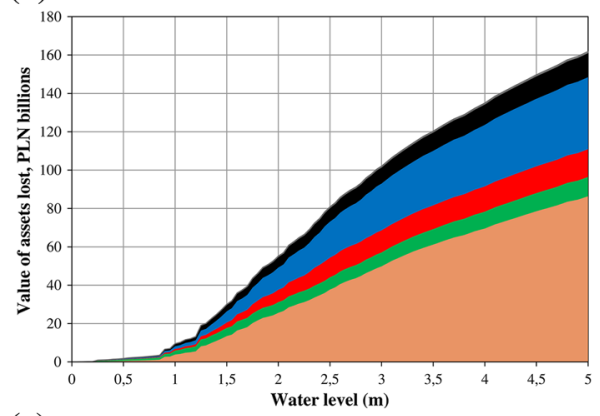

(c)

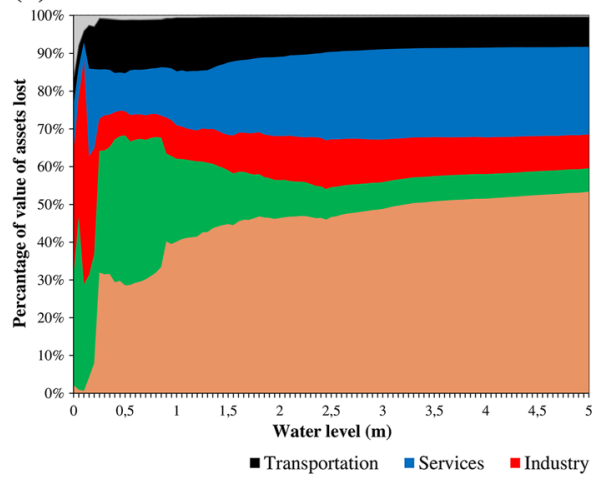

(b)

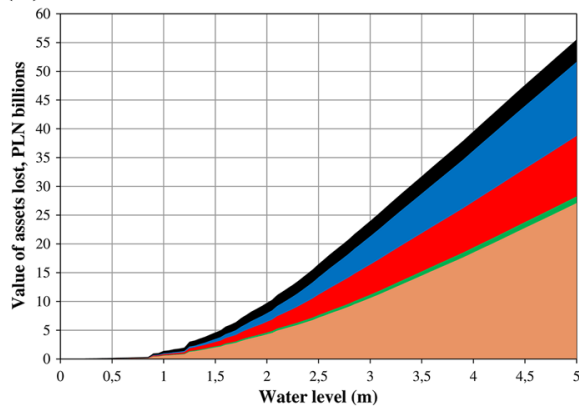

(d)

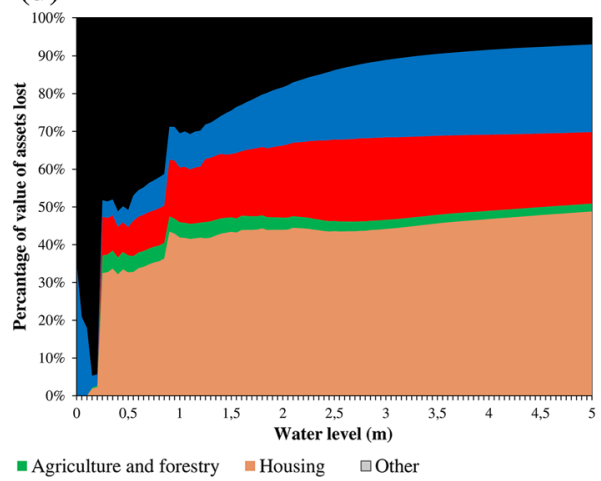

Fig. 7 Potential losses due to sea level rise: cumulative total values (a) and structural breakdown by activity (c). Potential losses due to coastal floods: cumulative total values (b) and structural breakdown by activity (d) 
manufacturing and utilities between $+1.3 \mathrm{~m}$ and $+2.4 \mathrm{~m} \mathrm{MSL}$; and tourist accommodation above that value. In total, land and buildings are almost equal in value up to $+0.85 \mathrm{~m}$ MSL, when the losses associated with the latter increase sharply. Buildings constitute more than $60 \%$ of losses at water levels above $+1.45 \mathrm{~m}$ MSL and more than $70 \%$ above $+2.4 \mathrm{~m}$ MSL, before peaking at $74 \%$. The percentage of potential losses connected with infrastructure slowly increases with the water level, but generally stays around $10 \%$.

\subsection{Economic impact of coastal floods}

Coastal floods have a different impact on assets than sea level rise. As noticed in Table 3, losses of fixed assets depend on damage curves, while no land is lost permanently. Therefore, economic losses due to coastal floods exhibit a rather exponential behaviour (Fig. 7b, d). By contrast, damages caused by SLR resemble more a logarithmic curve. The total losses are estimated at 1.4 bln PLN (0.09\% of 2011 GDP) for a 1-m surge and 16.6 bln PLN (1.1\%) for a 2.5-m surge, provided that it occurs in the entire coastal zone (Fig. 7b). The breakdown of those losses by economic sectors is even more stable at various water levels than in case of SLR (Fig. 7d). Apart from water levels below the uncertainty range, where merely a few buildings or roads could be affected, housing dominates at around $40 \%$ of all losses. Industry comprises around $20 \%$ of total, while the services sector hovers up a growing fraction from less than $10 \%$ (below $+1 \mathrm{~m} \mathrm{MSL}$ ) to $23 \%$ ( $+5 \mathrm{~m} \mathrm{MSL})$. Assets in the agricultural sector are worth little and therefore are responsible for only a small percentage of losses (only $4 \%$ at $1 \mathrm{~m}, 2 \%$ at $3 \mathrm{~m}$ ). Infrastructure contributes significantly at low water levels (more than half of losses below $+0.5 \mathrm{~m} \mathrm{MSL}$ ), but less so for other scenarios; the percentage value drops below $30 \%$ at $+1.25 \mathrm{~m}$ and below $20 \%$ at $+1.9 \mathrm{~m}$, ultimately reaching $7 \%$ at $+5 \mathrm{~m}$ MSL.

Additional feature of coastal floods that is different than SLR is its recurring character. In Fig. 8, we present number of affected inhabitants and assets, where surge heights have been recalculated as return periods. Those return periods were combined with different SLR scenarios. It can be clearly seen that even small values of sea level rise decrease significantly the return periods of coastal floods. A total of 100,000 persons are in the hazard zone of a 500-year coastal flood, but with a 30-cm SLR (at lower end of IPCC projections), it becomes a 90-year event. The return period further decreases to 30 years with a $50-\mathrm{cm}$ SLR and as little as 2.5 years with a $1-\mathrm{m}$ SLR; at $2 \mathrm{~m}$, SLR itself would

(a)

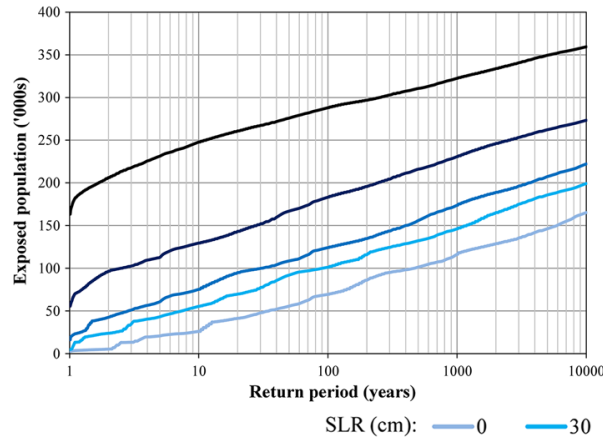

(b)

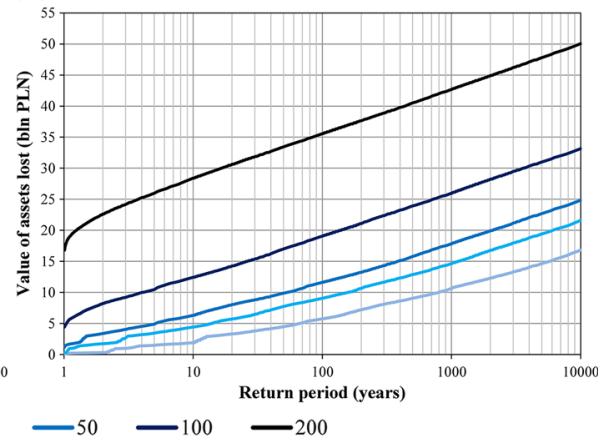

Fig. 8 Population (left) and assets (right) exposed to coastal flood by return period and sea level rise (SLR) scenario 
affect that number of people. Even a 10,000-year event becomes only a 50-year event at the upper range of IPCC projections. Potential economic losses also increase significantly - a 100-year event could cause 6 bln PLN (0.4\% of 2011 GDP) of damages under current conditions, but 19 bln PLN (1.2\%) with 1 m SLR.

\subsection{Temporal dimension of losses}

Previous sections looked at the total potential losses due to SLR and coastal floods at various scenarios, based on the distribution of land, population and assets in 2011. In this section, we analyse how those losses would be distributed over time according to IPCC sea level rise projections, and what would be the effect of future demographic evolution.

Sea level rise scenarios from the IPCC range from +0.28 (low) through +0.53 (medium) to $+0.98 \mathrm{~m}$ (high) increase in global MSL by 2100 . In Fig. 9a, the average yearly loss of assets (land, buildings, infrastructure) per decade is presented. It is assumed that value of assets will be constant relative to GDP. For comparison, annual expenditure on coastal protection (1) and flood defence (2) is provided (2004-2014 average; CSO 2015). The former corresponds to a mere 38 million PLN, but the lowest of the IPCC projections does not cause damage higher than that. In the medium scenario, damages exceed those costs so only in the $2050 \mathrm{~s}$. In the most severe projection, damage from SLR increases sharply in the end of the century, to about $0.03 \%$ of GDP per year, which equals about half of the yearly central government expenditure on disaster relief in Poland (2004-2014 average; CSO 2015).

Adding demographic evolution to the picture (Fig. 9b) shows that those values could change. The graph presents demographic evolution from 1960 to 2100 by hazard zone, using data by basic administrative unit for 1960-1988 from Eurostat (2015) and 1999-2014 from CSO (2015), together with future projections. Until recently, the population in the coastal zone increased faster than the national total. However, CSO (2015) projects that the population in the hazard zone corresponding to the low and medium scenarios will decrease substantially by the end of the century. Meanwhile, the population within the reach of the high scenario of SLR will increase in the medium term, decreasing slightly towards year 2100 . Additionally, the population currently endangered by $+1 \mathrm{~m}$ MSL is $49 \%$ urban, but this value will drop to $39 \%$ by 2050 . This is due to urban sprawl, i.e. the migration of wealthier people from cities to the surrounding rural municipalities,

(a)

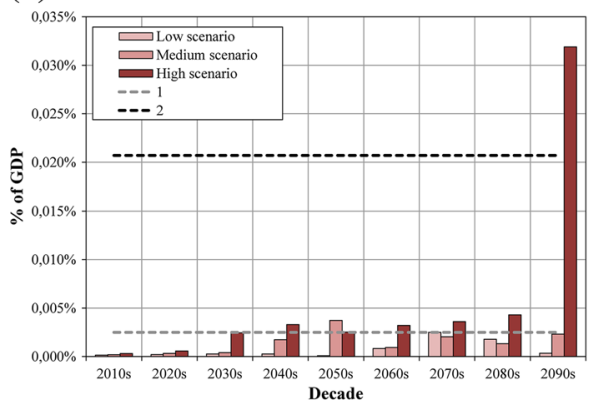

(b)

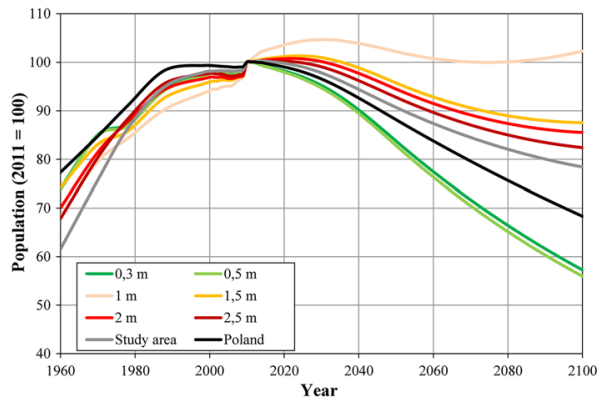

Fig. 9 Left potential losses due to inundation from sea level rise (annual averages by decade) with a comparison to average expenditure on (1) coastal protection (2) flood defences (2004-2014; CSO 2015). Right estimated population change by hazard zone (water level in $\mathrm{m}$ ) relative to 2011 census data 
particularly around the Tricity. It should be noted that we assume here that the population in an administrative unit will change by the same factor both in "endangered" and "safe" zones. It is difficult to conclude whether the population is likely to relocate towards more flood-prone areas. However, $3 \%$ of buildings located below $+1 \mathrm{~m}$ MSL were under construction at the time of the last update of the topographic objects database, slightly more than the percentage for the entire study area.

\subsection{Adaptation}

Adaptation to inundation caused by SLR could be done by raising flood defences. Full protection can be cost-effective, as indicated in Fig. 10a. At $+0.5 \mathrm{~m}$ MSL, investing 83 million PLN saves almost 1.5 bln PLN of damages (almost $0.1 \%$ of GDP), though loss of land worth 267 million PLN still occurs. By $+1 \mathrm{~m} \mathrm{MSL}$, investments rise to 1.9 bln PLN, but 7.3 bln PLN (0.5\% of GDP) is spared. Annualized, the costs of flood defences and loss of land are small. In Fig. 10b, they are compared with annual coastal protection expenditure (grey line), and until the 2080s, the adaptation costs are smaller. Also, even the costs in the 2090s in the high scenario of SLR are a quarter of current yearly investments on dikes (relative to GDP), and only $7 \%$ of annual disaster relief spending in Poland. Full protection at $+1 \mathrm{~m}$ MSL would require $654 \mathrm{~km}$ of new/upgraded dikes (Fig. 10c), of which about a third in the area of responsibility of the maritime administration and the rest around inland waters maintained by water management authorities. This proportion mostly

(a)

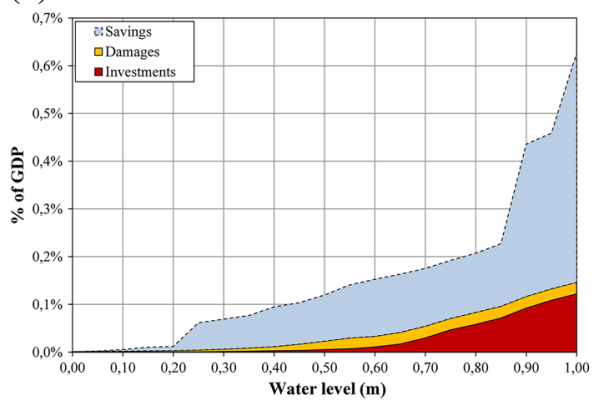

(c)

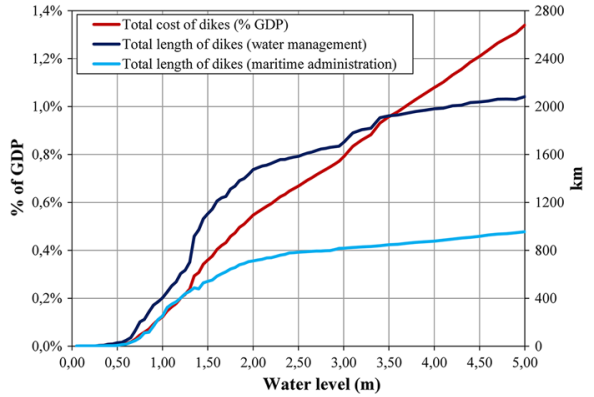

(b)

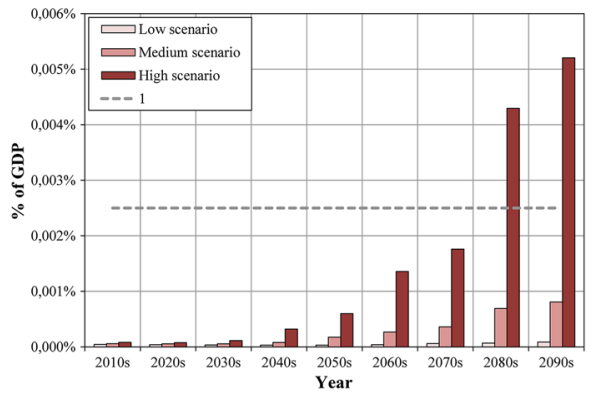

(d)

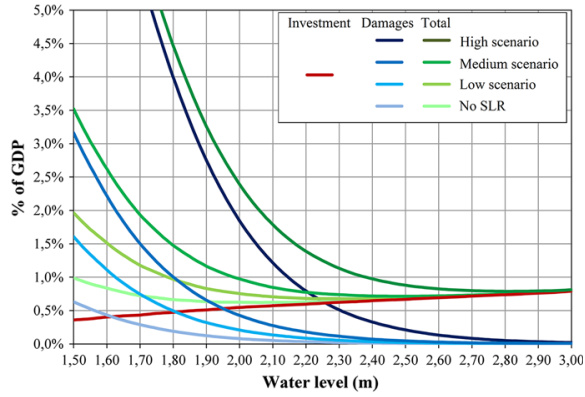

Fig. 10 Investments in defences against sea level rise, remaining damages (losses) and savings (a), annualized investments plus remaining losses for SLR scenarios; 1-annual coastal protection expenditure (b), length of flood defences and its costs needed for full protection (c), expected damages (2016-2100 total) and investments in flood defences (d) 
holds for other water levels, while the length of defences for coastal flood protection increases to $1000 \mathrm{~km}$ at $+1.2 \mathrm{~m}$ and $2000 \mathrm{~km}$ at $+1.8 \mathrm{~m}$ MSL. Still, the defences could be more streamlined, also by enclosing some smaller channels and building pumping stations. At least a tenth of the dikes can be replaced with around 20 stations, saving investment costs, though increasing maintenance costs.

In Fig. 10d, the investments and expected losses during 2016-2100 are presented. Under current conditions, the economically optimal flood defence protection level for the entire coast is $+2.06 \mathrm{~m} \mathrm{MSL}$ (excluding the safety margin). When SLR is taken into account, the protection level increases to $+2.35 \mathrm{~m}$ MSL in case of low SLR and $+2.81 \mathrm{~m}$ MSL in the highest scenario. The cost estimate is also a higher: $0.79 \%$ of GDP in the highest scenario instead of $0.62 \%$ (both figures including about $0.05 \%$ of GDP in damages over 85 years). Those costs could be optimized further, if instead of one protection standard for the entire coast, we make this calculation at the level of basic administrative units. Under present climate, the adaptation costs and losses amount to $0.39 \%$ of GDP, and with SLR, they increase to $0.49-0.67 \%$. However, this calculation does not include potential loss of life to coastal floods, as it is not possible to assign an economic value to this factor. Nevertheless, the described protection levels reduce the expected number of affected inhabitants to $80-120$ per year.

\section{Discussion}

\subsection{Uncertainties}

As with all studies on SLR and coastal floods, also the results presented in the previous section have their limitations; there are also several sources of uncertainty. Many of those are described in Sect. 2. The most crucial is the accuracy of the representation of the terrain and flood defence structures. The effects of the DEM's nominal accuracy $(20 \mathrm{~cm}$ in most of the area) are presented in Fig. 11. The uncertainty is large around $+1 \mathrm{~m} \mathrm{MSL}$, but still improved compared to some other, similar studies.

The data used to derive the exposure of assets also carry some uncertainty. Actual damage depends largely on buildings' construction characteristics and type of preparations made before the flood (Apel et al. 2009). Additionally, the equations used here were developed in Germany, since there is no methodology based on Polish empirical data. For the sake of illustration, in Fig. 12 we compare the results of coastal flood damage estimation using Polish government methodology (Law 2013/104), generic damage functions for European countries from Huizinga (2007) and a Dutch methodology made by Rijkswaterstaat (Kok et al. 2004). Some large discrepancies could be observed, even though it is partially a result of a different classification of assets in those methods.

We also use a simplification commonly applied in both to local and global studies that SLR is the only influence of climate change on extreme water levels (Xu and Huang 2013; Hinkel et al. 2014; Muis et al. 2015). Yet, recent modelling studies indicate that changes in wind regime will mostly cause a further increase in storm surge maxima, also in the Baltic (Gräwe and Burchard 2012; Vousdoukas et al. 2016). Furthermore, some dynamic effects of the sea level rise were omitted. Erosion and sedimentation could substantially change the level of hazard. In the context of flood hazard, the important information is whether erosion will destroy the barriers separating the inland from seawater. We did not analyse those aspects for a number of reasons. For one thing, in previous studies (e.g. Zeidler 1997; 


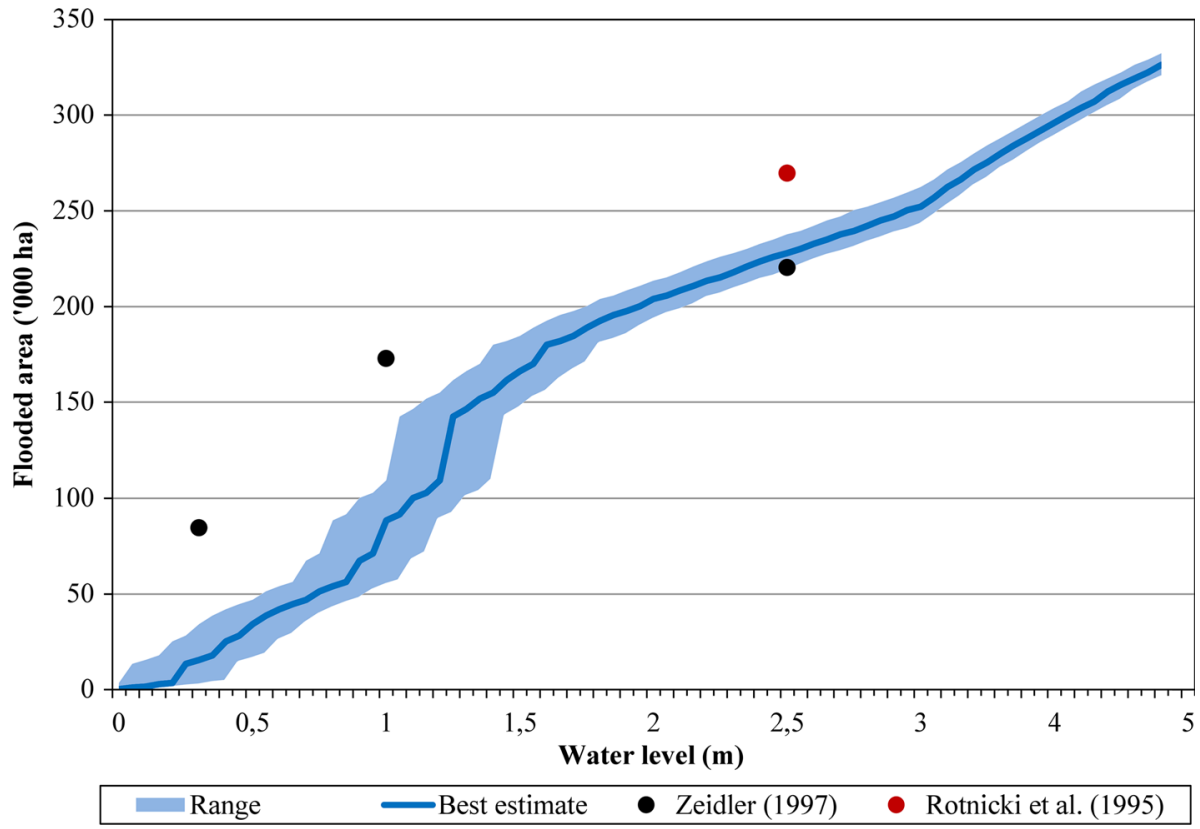

Fig. 11 Uncertainty in delimitation of the area affected by sea level rise, with comparison to two previous studies

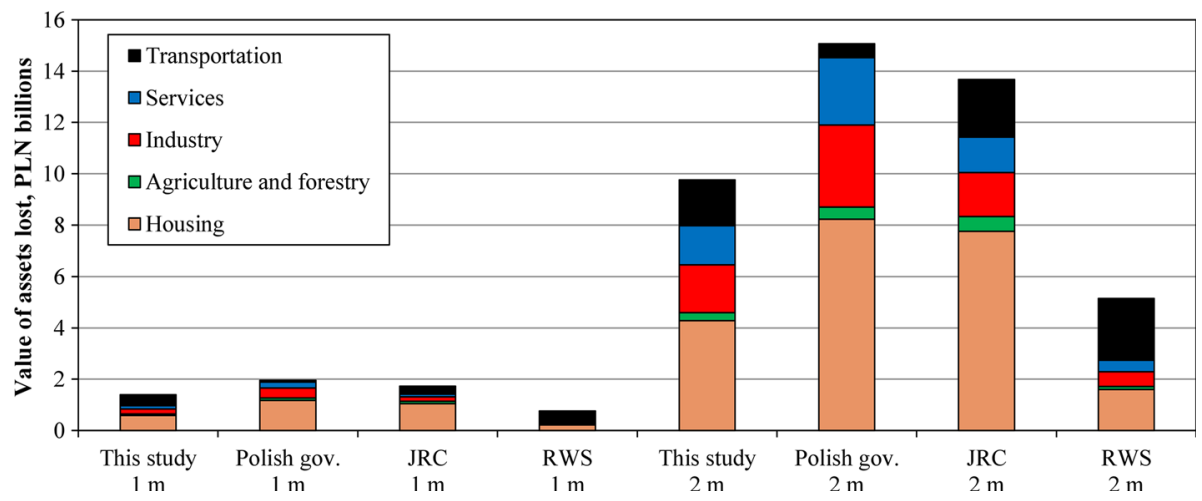

Fig. 12 Comparison of potential damage estimates from a 1- and 2-m storm surge using three alternate methodologies from the Polish government (Law 2013/104), JRC Joint Research Center (Huizinga 2007) and RWS Rijkswaterstaat (Kok et al. 2004)

Bosello et al. 2012), the issue was investigated as a separate problem than flooding, i.e. changes in topography were not included in the delimitation of hazard zones. Thus, a "static" approach gives us comparability with the results of those previous studies, especially since the focus of the paper is on inundation caused by sea level rise and coastal floods. Additionally, there is substantial variation along the Polish coast of erosion and sedimentation rates, and their impact on local morphology is still being investigated (Deng et al. 2014; Furmańczyk et al. 2014). Furthermore, the aforementioned studies considered 
coastal erosion as a much smaller source of losses than inundation of land by sea level rise and, foremost, coastal floods.

Similarly, the increase in groundwater levels caused by SLR is not analysed here, though this may result in inundation of low-lying areas otherwise fully protected from seawater. This aspect has not yet been properly investigated (Rotzoll and Fletcher 2013), especially in relation to the Polish coast. Salt intrusion is yet another issue, though the previous studies (Pluijm et al. 1992; Zeidler 1997; Bosello et al. 2012) considered potential damages to be minimal, and this aspect does not influence the level of flood hazard.

Another concern is the use of only eight tide gauges for the calculation of return periods the analysis of flood protection. In the open coast is not a large concern, as the difference between gauges in the 100-year return period is only $12 \mathrm{~cm}$, but inaccuracies occur in the Vistula and Odra rivers mouths as well as the coastal lagoons. Furthermore, the "bathtub fill" method exaggerates storm surge hazard. An actual overtopping of flood defences would mostly cause inundation of a much smaller area than indicated here, since the peak of the surge lasts only a short period of time. Breilh et al. (2013) estimates that the static method performs well for areas located no more than $3 \mathrm{~km}$ from the coast or estuary. In our case, around a third of the flood zone is within that limit for most scenarios (35\% for $+0.5 \mathrm{~m}, 31 \%$ for $+1.5 \mathrm{~m}, 33 \%$ for $+2.5 \mathrm{~m} \mathrm{MSL})$. However, the proportion of exposed buildings in the $3-\mathrm{km}$ zone increases from $8 \%$ for $+0.5 \mathrm{~m}$ to $39 \%$ for $+1.5 \mathrm{~m}$ and $53 \%$ for $+2.5 \mathrm{~m}$ MSL.

\subsection{Comparison with previous studies}

Our results can be contrasted with two studies that analysed impacts of sea level rise specifically on the Polish coast. Table 4 provides such a comparison, together with the estimated uncertainty of the results of this study (i.e. $\pm 20 \mathrm{~cm}$ accuracy of the DEM and $\pm 20 \%$ accuracy of assets value and population). Even taking the maximum values from our results, there is a substantial difference in estimates of exposure of inhabitants and assets. The primary reason is methodological: flood zones in Rotnicki and Borówka (1991) were delimitated without taking into account numerous barriers between the sea and lowlying areas, which was not possible at the resolution of their source material. Rotnicki et al. (1995) provided results for only one hazard zone of $+2.5 \mathrm{~m}$ MSL apart from identifying assets lying below sea level. According to the authors, the $2.5-\mathrm{m}$ contour represents the water level of a 100-year storm surge $(1.5 \mathrm{~m})$ superimposed on top of $1 \mathrm{~m}$ SLR. As presented in Table 4, the flooded area calculated by Rotnicki et al. is about $18 \%$ larger than our results indicate. The difference increases when analysing the number of exposed inhabitants. Rotnicki et al. put it at almost 300,000 persons, while in this study, it is nearly $50 \%$ lower. It should be noted that study refers to demographic situation in the late 1980s, but the Polish population numbers barely changed since then. Such a big difference can be explained by the fact that densely populated areas are mostly well protected by flood defences, which were not taken into account in that study.

A complementary study called VA'92 (Ziedler 1997) provides data for three flood zones, namely $+0.3,1$ and $2.5 \mathrm{~m}$ MSL and for two time periods: 1995 and 2025. As given in Table 4, the inundated area is six times larger at $+0.3 \mathrm{~m}$ MSL in VA'92 compared to this study, but the difference decreases with higher water levels, converging at $+2.5 \mathrm{~m}$ MSL. Number of inhabitants at risk is substantially lower than in VA'92, while the value of assets is even more so. At the time of that study, Polish population was forecasted to increase in the future, hence the big difference for the 2025 scenario; currently, the population is expected to decrease. Particularly striking is the difference in relative economic 
Table 4 Impacts of sea level rise in Poland: comparison of results from this analysis with VA'92 study as reported by Zeidler (1997) and a study by Rotnicki et al. (1995)

\begin{tabular}{|c|c|c|c|c|c|c|}
\hline \multirow{2}{*}{$\begin{array}{l}\text { Category } \\
\text { Reference period }\end{array}$} & \multirow{2}{*}{$\begin{array}{l}\text { Water } \\
\text { level } \\
(\mathrm{m})\end{array}$} & \multicolumn{2}{|c|}{ This study } & \multicolumn{2}{|c|}{ Zeidler (1997) } & \multirow{2}{*}{$\begin{array}{l}\text { Rotnicki et al. } \\
(1995) \\
\text { ca. } 1990\end{array}$} \\
\hline & & 2011 & & 1995 & 2025 & \\
\hline \multirow[t]{3}{*}{ Flooded area $\left(\mathrm{km}^{2}\right)$} & 0.30 & 155.2 & (16.4-341.8) & 845.1 & 845.1 & - \\
\hline & 1.00 & 885.0 & $(541.3-1,093.4)$ & 1727.7 & 1727.7 & - \\
\hline & 2.50 & 2278.4 & $(2178.4-2376.5)$ & 2203.3 & 2203.3 & 2696.7 \\
\hline \multirow[t]{3}{*}{ Persons affected } & 0.30 & 1777 & $(0-3362)$ & 40,860 & 64,600 & - \\
\hline & 1.00 & 19,966 & $(4245-33,432)$ & 146,040 & 230,600 & - \\
\hline & 2.50 & 167,503 & $(112,497-230,672)$ & 234,840 & 371,600 & 297,135 \\
\hline \multirow{3}{*}{$\begin{array}{l}\text { Value of assets at risk } \\
\text { (bln PLN at } 2011 \\
\text { prices) }\end{array}$} & 0.30 & 1.1 & $(0.1-2.2)$ & 47.8 & 78.1 & - \\
\hline & 1.00 & 9.6 & $(2.5-15.9)$ & 223.2 & 366.7 & - \\
\hline & 2.50 & 80.9 & $(55.3-107.6)$ & 366.7 & 574.0 & - \\
\hline \multirow{3}{*}{$\begin{array}{l}\text { Value of assets at risk (\% } \\
\text { GDP) }\end{array}$} & 0.30 & $0.1 \%$ & $(0.0-0.1 \%)$ & $7.5 \%$ & $3.1 \%$ & - \\
\hline & 1.00 & $0.6 \%$ & $(0.2-1.0 \%)$ & $35.0 \%$ & $14.6 \%$ & - \\
\hline & 2.50 & $5.2 \%$ & $(3.6-6.9 \%)$ & $57.5 \%$ & $22.9 \%$ & - \\
\hline \multirow{3}{*}{$\begin{array}{l}\text { Railway lines (without } \\
\text { sidings) affected (km) }\end{array}$} & 0.30 & 2.4 & $(1.4-3.1)$ & 35 & 35 & - \\
\hline & 1.00 & 25.5 & $(7.7-28.6)$ & 180 & 180 & - \\
\hline & 2.50 & 160 & $(138-185)$ & 219 & 219 & 347 \\
\hline \multirow{3}{*}{$\begin{array}{l}\text { Cost of dikes for full } \\
\text { protection (bln PLN at } \\
2011 \text { prices) }\end{array}$} & 0.30 & 0.02 & $(0.003$ to -0.1$)$ & 15.9 & 27.9 & - \\
\hline & 1.00 & 1.9 & $(0.7-3.7)$ & 28.7 & 62.1 & - \\
\hline & 2.50 & 10.2 & $(7.6-13.1)$ & - & - & - \\
\hline \multirow{3}{*}{$\begin{array}{l}\text { Cost of dikes for full } \\
\text { protection (\% GDP) }\end{array}$} & 0.30 & $0.001 \%$ & $(0-0.007 \%)$ & $2.5 \%$ & $1.1 \%$ & - \\
\hline & 1.00 & $0.1 \%$ & $(0.05-0.2 \%)$ & $4.4 \%$ & $2.5 \%$ & - \\
\hline & 2.50 & $0.7 \%$ & $(0.5-0.9 \%)$ & - & - & - \\
\hline
\end{tabular}

Cost of dikes in Zeidler's study was calculated using its earlier iteration (Pluijm et al. 1992)

losses, estimated at $0.6 \%$ of GDP, while VA'92 study gives an extremely high value of $35 \%$ for 1995 , forecasted to decrease to $15 \%$ by 2025 . That study also looked at adaptation and estimated that very large investments will be needed: Table 4 compares the cost of providing full protection by building and upgrading dikes. Zeidler's study does not give all information, but notes that $350 \mathrm{~km}$ of defences would be necessary to protect the Odra estuary against $30 \mathrm{~cm}$ SLR, and $604 \mathrm{~km}$ for $1 \mathrm{~m}$ SLR and at least the same amount for the Żuławy area; in the latter scenario, Pluijm et al. (1992) gave a value of $699 \mathrm{~km}$. In our analysis, the figures are 10 and $654 \mathrm{~km}$, respectively, for the entire coast. This is because we include in the delimitation of hazard zones the majority of existing defences, in contrast to the other study which omitted most of them.

More recently, an analysis of impacts of SLR in Europe using DIVA model was carried out by Bosello et al. (2012). For a comparable scenario (+0.95 m MSL), it gave an estimate of inundated area that is four time higher than in this study. Yet, it has put the value of inundated land at only $0.03 \%$ GDP in contrast to our estimate of $0.15 \%$, though the former figure refers to the projected economic situation in 2085 instead of the current situation. That study also expects that rising waters will cause the GDP to drop by $0.046 \%$, 
which is in line with our estimate of a $0.041 \%$ loss in commercial fixed assets. Meanwhile, Hinkel et al. (2010) estimated the expected number of inhabitants affected by coastal floods (without adaptation, but including demographic developments) as 30,000-60,000 per year in 2100 assuming a modest sea level rise of $35-45 \mathrm{~cm}$. For comparable water levels, we estimate the expectation at about 29,000-35,000 persons.

In order to further assess the impacts of quality of data on our results, we have juxtaposed them with official flood hazard maps (KZGW 2015). Those studies were prepared for selected parts of the coast, utilizing two-dimensional hydrodynamic modelling and locally collected data, such as detailed surveys on flood protection structures and administrative registers and databases. They mostly cover a single 500-year flood scenario, which translates into water levels of 1.7-3.0 m above MSL depending on location. Most of those maps present very similar flood zones, with the main exception being the Żuławy Wiślane area, which is protected by a more elaborate flood defence system of pumps, sluices and weirs. Table 5 presents estimates of inhabitants exposed to coastal floods in the main coastal cities in Poland. Scenario A denotes our approximation of the KZGW's storm surge scenarios. In the KZGW maps, water level is spatially variable, because a hydrodynamic model was applied to calculate the effects of surges. The results show that the difference between our results and the official maps is mostly small, though in every case, our estimates of the number of inhabitants exposed are higher. However, part of the difference could be the effect of different sources of demographic data used in both studies. KZGW used detailed data from the population register instead of disaggregated estimates that are used here. In Table 5, we also include the number of exposed inhabitants using our calculations of return periods (B). They are mostly lower than KZGW scenario, which is probably caused by inclusion of a larger number of water level observations and different

Table 5 Impacts of coastal floods in selected major coastal cities

\begin{tabular}{|c|c|c|c|c|c|c|}
\hline \multirow[t]{2}{*}{ City } & \multirow{2}{*}{$\begin{array}{l}\text { Population in } 2011 \\
\text { ('000s) }\end{array}$} & \multicolumn{2}{|c|}{ Water level (m) } & \multicolumn{3}{|c|}{ Exposed population ('000s) } \\
\hline & & $A$ & $B$ & This study $(A)$ & This study $(B)$ & KZGW maps \\
\hline \multirow[t]{2}{*}{ Szczecin } & \multirow[t]{2}{*}{410.1} & 1.85 & 1.63 & 2.5 & 1.7 & 1.8 \\
\hline & & 1.60 & 0.99 & 1.6 & 1.1 & 1.3 \\
\hline Police & 34.0 & 1.75 & 1.63 & 0.2 & 0.2 & 0.1 \\
\hline \multirow[t]{2}{*}{ Świnoujście } & \multirow[t]{2}{*}{41.5} & 2.60 & 1.93 & 15.4 & 7.7 & 14.1 \\
\hline & & 2.30 & 1.21 & 11.2 & 4.2 & 9.6 \\
\hline Kołobrzeg & 47.1 & 2.00 & 1.98 & 0.7 & 0.6 & 0.3 \\
\hline Ustka & 16.4 & 2.60 & 1.85 & 1.2 & 0.5 & 0.8 \\
\hline Gdynia & 249.1 & 2.35 & 1.96 & 0.2 & Nil & 0.0 \\
\hline Sopot & 38.7 & 2.50 & 1.96 & 1.3 & Nil & 0.2 \\
\hline \multirow[t]{2}{*}{ Gdańsk } & \multirow[t]{2}{*}{460.3} & 2.50 & 1.96 & 38.4 & 14.7 & 34.7 \\
\hline & & 2.10 & 1.20 & 22.3 & 7.0 & 20.0 \\
\hline Elbląg & 124.7 & 1.40 & 1.96 & 2.0 & 3.0 & 0.7 \\
\hline
\end{tabular}

Water level in the table is $(A)$ an approximation of KZGW's 100- or 500-years flood scenarios and $(B)$ our calculation of 100- or 500-year coastal flood 
methodology of return period calculations in that study. In effect, our estimate of the number of affected inhabitants for a comparable return period is lower.

\section{Conclusions}

In this paper, we have undertaken a broad analysis of potential impacts of inundation caused by sea level rise and coastal floods in the Polish coastal zone. Its aim was to increase the accuracy and level of detail of country-wide risk estimates, covering both population and economics, compared to currently available studies. This was made possible by recent developments in the national stock of spatial data. The most important findings of the study are:

- Impacts of SLR, as well as adaptation costs to SLR, will be much smaller than indicated in previous studies. $1 \mathrm{~m}$ SLR would affect directly 20,000 inhabitants and 9.6 bln PLN of assets ( $0.6 \%$ of GDP), while the cost of increasing flood defences for full protection of the population would be 1.9 bln PLN.

- Annualized, adaptation costs and remaining losses would be equivalent of a fraction of average coastal protection budget (about $0.0025 \%$ of GDP); only in the highest IPCC projection, the budget would have to be more than doubled by the 2080s.

- Coastal floods will increase substantially in frequency due to sea level rise. Half-meter SLR will double the number of inhabitants and assets in the 100-year flood zone, while $1 \mathrm{~m}$ SLR will more than triple it. Economically optimal flood defences would cost $0.39 \%$ of GDP at current climate conditions, and $0.49-0.67 \%$ of GDP within SLR scenarios indicated by IPCC.

- Rural population would be proportionately much more exposed than inhabitants in urban areas. Assets used in agricultural production are the most exposed category within the range of IPPC projections of SLR. For higher SLR values and coastal floods, housing comprises the biggest percentage of assets at risk, at about $40 \%$.

- SLR will have very limited direct impact on the regionally important tourist industry. However, the beaches and natural reserves which draw the visitors are among the most vulnerable: more than half of the land in the $+1 \mathrm{~m}$ MSL hazard zone is under some kind of environmental protection.

But again, one should bear in mind that several simplifications have been used in this study and more research is required, especially on coastal flood scenarios, damage curves, future climate, population and economic projections. More advanced modelling techniques that take into account dynamics of storm surges and coastal processes (erosion and sedimentation) are yet to be used in the Polish coastal zone.

Acknowledgments The authors would like to thank the Central Surveying and Cartographic Documentation Center (CODGiK) in Warsaw, Poland, for kindly providing the topographic objects database and digital elevation models used in this study. Special thanks should be extended to S. N. Jonkman for his comments on the draft of this paper, as well as to the anonymous referees for their detailed suggestions which helped to improve this paper significantly.

Open Access This article is distributed under the terms of the Creative Commons Attribution 4.0 International License (http://creativecommons.org/licenses/by/4.0/), which permits unrestricted use, distribution, and reproduction in any medium, provided you give appropriate credit to the original author(s) and the source, provide a link to the Creative Commons license, and indicate if changes were made. 


\section{References}

Apel H, Aronica GT, Kreibich H, Thieken AH (2009) Flood risk analyses-how detailed do we need to be? Nat Hazards 49:79-98. doi:10.1007/s11069-008-9277-8

Bates P, De Roo AP (2000) A simple raster-based model for flood inundation simulation. J Hydrol 236:54-77. doi:10.1016/S0022-1694(00)00278-X

Bednarczyk S, Jarzębińska T, Mackiewicz S, Wołoszyn E (2006) Vademecum ochrony przeciwpowodziowej. Krajowy Zarząd Gospodarki Wodnej, Gdańsk

Bosello F, Nicholls RJ, Richards J, Roson R, Tol RSJ (2012) Economic impacts of climate change in Europe: sea-level rise. Clim Change 112:63-81. doi:10.1007/s10584-011-0340-1

Breilh JF, Chaumillon E, Bertin X, Gravelle M (2013) Assessment of static flood modeling techniques: application to contrasting marshes flooded during Xynthia (western France). Nat Hazards Earth Syst Sci 13:1595-1612. doi:10.5194/nhess-13-1595-2013

Cardona OD, van Aalst MK, Birkmann J, Fordham M, McGregor G, Perez R, Pulwarty RS, Schipper ELF, Sinh BT (2012) Determinants of risk: exposure and vulnerability. In: Field CB, Barros V, Stocker TF, Qin D, Dokken DJ, Ebi KL, Mastrandrea MD, Mach KJ, Plattner GK, Allen SK, Tignor M, Midgley PM (eds) Managing the risks of extreme events and disasters to advance climate change adaptation. Cambridge University Press, Cambridge and New York, pp 65-108

Church JA, White NJ (2011) Sea-level rise from the late 19th to the early 21st century. Surv Geophys 32:585-602. doi:10.1007/s10712-011-9119-1

Church JA, Clark PU, Cazenave A, Gregory JM, Jevrejeva S, Levermann A, Merrifield MA, Milne GA, Nerem RS, Nunn PD, Payne AJ, Pfeffer WT, Stammer D, Unnikrishnan AS (2013) Sea level change. In: Stocker TF, Qin D, Plattne GK, Tignor M, Allen SK, Boschung J, Nauels A, Xia Y, Bex V, Midgley PM (eds) Climate change 2013: the physical science basis contribution of working group I to the fifth assessment report of the intergovernmental panel on climate change. Cambridge University Press, Cambridge and New York, pp 1137-1216

CODGiK (2014) Numeryczne Dane Wysokościowe. http://www.codgik.gov.pl/index.php/zasob/ numeryczne-dane-wysokosciowe.html. Accessed 11 Dec 2014

CODGiK (2016) Baza Danych Obiektów Topograficznych BDOT10k http://www.codgik.gov.pl/index.php/ zasob/baza-danych-obiektow-topograficznych.html. Accessed 27 Jul 2016

CSO (2015). http://stat.gov.pl/en/. Accessed 12 Sept 2015

Deng J, Zhang WY, Schneider R, Harff J, Dudzińska-Nowak J, Terefenko P, Giza A, Furmańczyk K (2014) A numerical approach for approximating the historical morphology of wave-dominated coasts-a case study of the Pomeranian Bight, southern Baltic Sea. Geomorphology 204:425-443. doi:10.1016/j. geomorph.2013.08.023

Eijgenraam CJJ (2006) Optimal safety standards for dike-ring areas. CPB Netherlands Bureau for Economic Policy Analysis Discussion Paper 62

Ekman M (2009) The changing level of the Baltic Sea during 300 years: a clue to understanding the Earth. Summer Institute for Historical Geophysics, Ảland Islands

Emschergenossenschaft/Hydrotec (2004) Hochwasser-Aktionsplan Emscher-Methodik der Schadensermittlung. http://www.eglv.de/fileadmin/EmscherGenossenschaft/2.3_Flussgebietsmanagement/ Karten_Anlage/Methodik_der_Schadensermittlung/methodik_schadensermittlung.pdf. Accessed 12 Sept 2015

EU (2007) Directive 2007/60/EC of the European Parliament and of the Council of 23 October 2007 on the assessment and management of flood risks. OJ L 288:27-34

Eurostat (2015). http://epp.eurostat.ec.europa.eu/portal/page/portal/statistics/themes. Accessed 27 Aug 2015

Furmańczyk K, Andrzejewski P, Benedyczak R, Bugajny N, Cieszyński Ł, Dudzińska-Nowak J, Giza A, Paprotny D, Terefenko P, Zawiślak T (2014) Recording of selected effects and hazards caused by current and expected storm events in the Baltic Sea coastal zone. J Coast Res Special Issue 70:338-342. doi:10.2112/SI70-057.1

Gräwe U, Burchard H (2012) Storm surges in the Western Baltic Sea: the present and a possible future. Clim Dyn 39:165-183. doi:10.1007/s00382-011-1185-Z

Hallegatte S (2012) A framework to investigate the economic growth impact of sea level rise. Environ Res Lett 7:015604. doi:10.1088/1748-9326/7/1/015604

Hinkel J, Nicholls RJ, Vafeidis AT, Tol RS, Avagianou T (2010) Assessing risk of and adaptation to sealevel rise in the European Union: an application of DIVA. Mitig Adapt Strateg Glob Change 15:703-719. doi:10.1007/s11027-010-9237-y

Hinkel J, Linckea D, Vafeidis AT, Perrettec M, Nicholls RJ, Tol RSJ, Marzeion B, Fettweis X, Ionescu C, Levermann A (2014) Coastal flood damage and adaptation costs under 21st century sea-level rise. Proc Natl Acad Sci USA 111:3292-3297. doi:10.1073/pnas.1222469111 
Huizinga H (2007) Flood damage functions for EU member states. JRC-Institute for Environment and Sustainability/HKV Consultants: Lelystad

Hunter J (2010) Estimating sea-level extremes under conditions of uncertain sea-level rise. Clim Change 99:331-350. doi:10.1007/s10584-009-9671-6

Jonkman SN, Hillen MM, Nicholls RJ, Kanning W, van Ledden M (2013) Costs of adapting coastal defences to sea-level rise-new estimates and their implications. J Coast Res 29:1212-1226

Kok M, Huizinga H, Vrouwenvelder A, Barendregt A (2004) Standaardmethode2004—Schade en Slachtoffers als gevolg van overstromingen. DWW-2005-005, RWS Dienst Weg-en Waterbouwkunde

Kron F (2005) Flood risk = hazard * values * vulnerability. Water Int 30(1):58-68. doi:10.1080/ 02508060508691837

Kummu M, de Moel H, Salvucci G, Viviroli D, Ward PJ, Varis O (2016) Over the hills and further away from coast: global geospatial patterns of human and environment over the 20th-21st centuries. Environ Res Lett 11(3):034010. doi:10.1088/1748-9326/11/3/034010

KZGW (2011) Raport z wykonania wstępnej oceny ryzyka powodziowego. KZGW, Warszawa. http://www. kzgw.gov.pl/pl/Wstepna-ocena-ryzyka-powodziowego.html. Accessed 10 Feb 2015

KZGW (2015) Informatyczny System Osłony Kraju. http://mapy.isok.gov.pl/imap/. Accessed 10 Feb 2015

Łonyszyn P, Terefenko O (2014) Creation of an alternative season based on sustainable tourism as an opportunity for Baltic Sea Region. J Coast Res Special Issue 70:454-459. doi:10.2112/SI70-077.1

Merz B, Kreibich H, Thieken A, Schmidtke R (2004) Estimation uncertainty of direct monetary flood damage to buildings. Nat Hazards Earth Syst Sci 4:153-163. doi:10.5194/nhess-4-153-2004

Ministry of Treasury (2012) Sprawozdanie o stanie mienia Skarbu Państwa. Warsaw. http://bip.msp.gov.pl/ download/1/5554/Sprawozdanie2011.pdf. Accessed 10 Feb 2015

Mokrech M, Kebede AS, Nicholls RJ, Wimmer F, Feyen L (2015) An integrated approach for assessing flood impacts due to future climate and socio-economic conditions and the scope of adaptation in Europe. Clim Change 128:245-260. doi:10.1007/s10584-014-1298-62015

Muis S, Guneralp B, Jongman B, Aerts JCJH, Ward PJ (2015) Flood risk and adaptation strategies under climate change and urban expansion: a probabilistic analysis using global data. Sci Total Environ 538:445-457. doi:10.1016/j.scitotenv.2015.08.068

Nicholls RJ, Klein RJT (2005) Climate change and coastal management on Europe's coast. In: Vermaat JE, Bouwer L, Turner K, Salomons W (eds) Managing European coasts: past, present and future, environmental science monograph series. Springer, Berlin, pp 199-226

Nicholls RJ, Mimura N (1998) Regional issues raised by sea-level rise and their policy implications. Clim Res 11:5-18

NOAA (2016) Sea level rise maps. http://www.star.nesdis.noaa.gov/sod/lsa/SeaLevelRise/LSA_SLR_maps. php. Accessed 27 Jul 2016

Paprotny D (2014) Trends in storm surge probability of occurrence along the Polish Baltic Sea coast. arXiv: 1410.2547

Peltier WR, Argus DF, Drummond R (2015) Space geodesy constrains ice-age terminal deglaciation: the global ICE-6G_C (VM5a) model. J Geophys Res Solid Earth 120:450-487. doi:10.1002/ 2014JB011176

Permanent Service for Mean Sea Level (2015). http://www.psmsl.org/data/obtaining/map.html. Accessed 8 Jan 2015

Pfeffer WT, Harper JT, O’Neel S (2008) Kinematic constraints on glacier contributions to 21st century sea level rise. Science 321:1340-1343. doi:10.1126/science.1159099

Piketty T, Zucman G (2014) Capital is back: wealth-income ratios in rich countries, 1700-2010. Q J Econ 129:1155-1210. doi:10.1093/qje/qju018

Pluijm M, Toms G, Zeidler RB, van Urk A, Misdorp R (1992) Vulnerability assessment to accelerated sea level rise: case study Poland. Ministry of Transport, Public Works and Water Management, The Hague

Poulter B, Halpin PN (2008) Raster modelling of coastal flooding from sea-level rise. Int J Geogr Inf Sci 22:167-182. doi:10.1080/13658810701371858

Pruszak Z, Zawadzka E (2005) Vulnerability of Poland's coast to sea-level rise. Coast Eng J 47:131-155. doi:10.1142/S0578563405001197

Pruszak Z, Zawadzka E (2008) Potential implications of sea-level rise for Poland. J Coast Res 24:410-422. doi:10.2112/07A-0014.1

Rahmstorf S (2007) Sea-level rise a semi-empirical approach to projecting future. Science 315:368-370. doi: $10.1126 /$ science. 1135456

Richter A, Groh A, Dietrich R (2012) Geodetic observation of sea-level change and crustal deformation in the Baltic Sea region. Phys Chem Earth 53-54:43-53. doi:10.1016/j.pce.2011.04.011 
Rotnicki K, Borowka RK (1991) Impact of a future sea level rise in the Polish Baltic coastal zone. EPA International Sea Level Rise Studies Project Report. Division of Coastal and Environmental Studies. Rutgers University Institute of Coastal and Marine Sciences, New Brunswick

Rotnicki K, Borówka RK, Devine N (1995) Accelerated sea level rise as a threat to the Polish Coastal Zone-quantification of risk. J Coast Res Special Issue 22:111-135

Rotzoll K, Fletcher CH (2013) Assessment of groundwater inundation as a consequence of sea-level rise. Nat Clim Change 3:477-481. doi:10.1038/nclimate1725

Statistisches Bundesamt (2015) Bau- und Immobilienpreise. https://www.destatis.de/DE/ZahlenFakten/ GesamtwirtschaftUmwelt/Preise/BauImmobilienpreise/BauImmobilienpreise.html. Accessed 21 Jan 2015

Tomczak A (1995) Geological structure and Holocene evolution of the Polish coastal zone. J Coast Res Special Issue 22:16-31

Urbański J (2012) GIS w badaniach przyrodniczych. University of Gdańsk, Gdańsk

Van Dantzig D (1956) Economic decision problems for flood prevention. Econometrica 24:276-287

Vousdoukas MI, Voukouvalas E, Annunziato A, Giardino A, Feyen L (2016) Projections of extreme storm surge levels along Europe. Clim Dyn. doi:10.1007/s00382-016-3019-5

Webster TL (2010) Flood risk mapping using LiDAR for Annapolis Royal, Nova Scotia, Canada. Remote Sens 2:2060-2082. doi:10.3390/rs2092060

Wiśniewski B, Kowalewska-Kalkowska H (2007) Water level fluctuations in the Odra River mouth area in relation to passages of deep low-pressure systems. Oceanol Hydrobiol Stud 36:69-82. doi:10.2478/ v10009-007-0009-2

Wiśniewski B, Wolski T (2009) Katalogi wezbrań i obniżeń sztormowych poziomów morza oraz ekstremalne poziomy wód na polskim wybrzeżu. Maritime University of Szczecin, Szczecin

Wiśniewski B, Wolski T, Musielak S (2011) A long-term trend and temporal fluctuations of the sea level at the Polish Baltic coast. Oceanol Hydrobiol Stud 40:96-107. doi:10.2478/s13545-011-0020-9

Wolski T, Wiśniewski B, Giza A, Kowalewska-Kalkowska H, Boman H, Grabbi-Kaiv S, Hammarklint T, Holfort J, Lydeikaite Ž (2014) Extreme sea levels at selected stations on the Baltic Sea coast. Oceanologia 56:259-290. doi:10.5697/oc.56-2.259

Wróblewski A (1994) Analysis and forecast of long-term sea level changes along the Polish Baltic Sea coast. Part II. Annual mean sea levels-forecast to the year 2100. Ocealonogia 36:107-120

Xu S, Huang W (2013) Effects of sea level rise on frequency analysis of $1 \%$ annual maximum water levels in the coast of Florida. Ocean Eng 71:96-102. doi:10.1016/j.oceaneng.2013.01.013

Zeidler RB (1997) Climate change vulnerability and response strategies for the coastal zone of Poland. Clim Change 36:151-173. doi:10.1023/A:1005394909182 